\title{
The Recognition of New States in Times of Secession: Is State Recognition Turning into Another Means of Intervention?
}

\author{
Patrick C. R. Terry'
}

\section{INTRODUCTION}

As globalization's effects are being felt more keenly even in the more rural areas of developed and developing states alike, many people's desire to withdraw into ever-smaller units seems to be increasing concurrently. Across the world, separatist movements are on the up, not only in the less fortunate, but also in established, seemingly successful states. Many observers probably expected war-torn, artificially created Iraq to be exposed to manifold wishes to secede by various parts of its population (notably, the Kurds). However, not that long ago, only few would have predicted that there would be a perhaps soon to be repeated serious attempt by Scotland to secede from the United Kingdom or an ongoing attempt by Catalonia to separate from Spain. It seems the view that "smaller is better" is gaining traction in defence against what many feel are the less attractive consequences of free-trade-agreements and internationalisation of every-day-life.

These developments give rise to many questions, not least in the sphere of international law. This article will look at the legal requirements for recognizing seceding entities as new states. The creation of a new state, after all, has far-reaching consequences: one of the most important being the right to invoke the right of collective self-defence, also in defence against the parent state. It follows that many view the recognition of a seceding entity by other states as the decisive indicator when judging a secession's

1 LL.M. (University of Kent); Ph.D. (University of Kent); Professor, Faculty of Law, University of Public Administration Kehl. 
success, as this acknowledgement of a new state's existence enables official bilateral support.

Before turning to secessions, it is necessary to outline the general, sometimes still contested rules in customary international law on the recognition of states. It will be shown that past attempts, mainly by European states, to impose new conditions on statehood, which could easily be construed as having violated the principle of non-intervention, have failed. Examining state practice and analysing the International Court of Justice's advisory opinion on Kosovo will then allow the conclusion that the general rules on recognition apply to seceding entities as well. The article will argue that the ICJ's view that, bar two circumscribed exceptions, international law does not address the legality of secessions is correct. It follows that the mere fact a new state has seceded does generally not affect other states' capacity to recognise it.

After thus outlining the current state of the law on recognition in times of secession, new developments in state practice will be scrutinized. Although sufficient opinio juris is still lacking, it seems states are incrementally moving towards accepting a new right in international law, namely a right of remedial secession. There are some indications that, as a consequence, states are willing to recognise a seceding entity lacking some or even all of the criteria of statehood in cases where they judge the secession as being justified based on the prior -real or alleged- mistreatment of the seceding population by the mother country. The article concludes by pointing out that this is a very dangerous development, as it encourages outside intervention in internal conflicts by internationalising it and thereby potentially legalizes the use of military force on behalf of the secessionists, based on collective self-defence.

\section{THE RECOGNITION OF STATES IN INTERNATIONAL LAW}

The recognition of states is governed by customary international law. Generally applicable rules have not been codified, attempts at doing so have failed. The ICJ, in its recent advisory opinion on Kosovo, also declined to address the topic. ${ }^{2}$ Due to this, the recognition of states has always been

2 Accordance with International Law of the Unilateral Declaration of Independence in Respect of Kosovo, Advisory Opinion, 2010 I.C.J. Rep. 403, 51 (July 22) [hereinafter ICJ Self-Government of Kosovo] (declaring that "it had not been asked 
somewhat controversial. Some have even argued that extending recognition is a purely political decision, ${ }^{3}$ while others disagree on the effects of and criteria for granting recognition.

However, specific rules of international law on state recognition have developed. ${ }^{4}$ Although state practice is not entirely consistent, the views expressed by governments and the many cases where like cases have been

whether or not Kosovo has achieved statehood," nor had it been asked "about the validity or legal effects of the recognition of Kosovo by those States which have recognised it as an independent state").

3 This is illustrated by the different approaches taken in the late 1940s. HersCH Lauterpacht, Recognition in International LaW at v (1947) (stating that " $[t]$ here are only few branches of international law which are of greater, or more persistent, interest and significance for the law of nations than the question of Recognition of States" and that "[y]et there is probably no other subject in the field of international relations in which law and politics appear to be more closely interwoven"); Philip Marshall Brown, The Recognition of Israel, 42 AMERICAN Journal of International LaW 620, 621 (1948) (“[I]n spite of the comments and theories of the writers on the subject of recognition the simple truth is that it is governed by no rules whatever ... the act of recognition is political in nature.”); Thomas D. Grant, Recognition of States: Law and Practice in Debate And Evolution 168 (1999) (“Whether recognition is a subject of law or of politics is indeed one of the centers of debate over recognition today."); Regarding Yugoslavia, see Hurst Hannum, Self-Determination, Yugoslavia, and Europe: Old Wine in New Bottles?, 3 Transnational Law and Contemporary Problems 57, 60 (1993); Marc Weller, Current Development: The International Responses to the Dissolution of the Socialist Federal Republic of Yugoslavia, 86 AMERICAN Journal of International Law 569, 587 (1992); John Dugard, The Secession of States and Their Recognition in the Wake of Kosovo 45-46 (2013).

4 For an approach to the recognition of states different from the one adopted here, see, e.g., Martti Koskenniemi, From Apology to Utopia: The Structure of International Legal Argument 272-82 (1989) (He claims both the declaratory and the constitutive theories are indefensible and do not "provide[] a satisfactory interpretation of state practice." He views the granting of recognition in practice as closely aligned to giving "political approval," id. at 243, because neither theory accepts a "duty to recognise" which, in turn, leads to contradictory results in practice.). 
treated alike evidence that states do feel bound by certain criteria when recognizing another state. ${ }^{5}$

Before setting out the content of these customary international law rules, it is necessary to examine what effect recognition of another state has, because this will determine the content of the legal rules on recognition.

\section{a. Constitutive or Declaratory Theory?}

There are two main theories as far as the effects of recognition on the recognised entity are concerned, the constitutive and the declaratory theory. ${ }^{6}$ More recently, various new theories have developed, which amount to a combination of elements of both theories.

The older constitutive theory is based on the notion that a state only comes into being by obtaining recognition from already existing states. This concept was originally based on $19^{\text {th }}$ century notions prevalent in Europe. ${ }^{7}$ The rulers of the European "family of nations" wanted it to be solely at their discretion whether they would accept and welcome a new

5 Roland Rich, Recognition of States: The Collapse of Yugoslavia and the Soviet Union, 4 European Journal of International Law 36, 55 (1993) (arguing that a "certain degree of consistency" in state practice developed in the $20^{\text {th }}$ century); J.J. Lador-Lederer, Recognition- A Historical Stocktaking, 27 Nordic JourNAL of International Law 64, 80 (1957) (quoting a British Government note to the United Nations of August 24, 1948, which states that "the recognition or nonrecognition of States is a matter of legal duty and not of policy").

6 See Stefan Talmon, The Constitutive Versus the Declaratory Theory of Recognition: Tertium Non Datur?, 75 British Yearbook of International Law 101 (2004), for a detailed examination of the debate and, in particular, of its relationship to the principle of non-recognition.

7 James Crawford, The Creation of States in International Law 14-16 (2d ed. 2006); Lador-Lederer, supra note 5, at 65, 67-76 ("concurrence of imperialism and constitutive theory"); Talmon, supra note 6, at 102. 
member into that family or not. ${ }^{8}$ Even the most absurd arrangement could be accepted as a state if it suited the recognizing ruler. ${ }^{9}$

The constitutive theory still has adherents, who argue that an entity not recognised by other states simply cannot function properly in international law, and that the ability to act as a legal personality is obtained by recognition. ${ }^{10}$ Modern proponents of the constitutive theory, however, have often modified the original concept by laying down certain conditions entities must fulfil before they can be recognised as states, and by imposing a duty on other states to extend recognition once these conditions have been met. ${ }^{11}$

In the course of the $20^{\text {th }}$ century the declaratory theory, however, has become the dominant view regarding the effect of recognition. ${ }^{12}$ The act of

8 Lador-Lederer, supra note 5, at 77-78; CRAWFORD, supra note 7, at 14-16.

9 Crawford, supra note 7, at 14-16; Lador-Lederer, supra note 5, at 72 (providing the examples of the recognitions of the Republic of Cracow in 1815, the creation of the State of the Ionian Islands in 1815, and the creation of the State of Albania in 1913).

10 Christian Hillgruber, The Admission of New States to the International Community, 9 European Journal of International LAW 491, 491-94 (1998); LAUTERPACHT, supra note 3, at 5-7; Jure Vidmar, Territorial Integrity and the Law of Statehood, 44 George Washington International Law Review 736, 743 (2012) (though limiting this to exceptional cases).

11 LaUterpacht, supra note 3, AT 5-7; TAlmon, supra note 6, AT 103 (describing these views).

12 Herbert W. Briggs, Recognition of States: Some Reflections on Doctrine and Practice, 43 American Journal of International Law 113, 117 (1949); José Maria Ruda, Recognition of States and Governments in International Law: Achievements and Prospects 449, 454 (Mohammed Bedjaoui ed., 1991); John O’Brien, International Law 172 (2001); Hilary Charlesworth \& Christine Chinkin, The Boundaries of International Law: a Feminist Analysis 140 (2000); Jorri Duursma, Fragmentation and the International Relations of Micro-States 115 (1996); Stephanie Baer, Der Zerfall Jugoslawiens im Lichte des VöLKerRechts 323-24 (1995); Thomas D. Grant, Territorial Status, Recognition and Statehood: Some Aspects of the Genocide Case (Bosnia and Herzegovina v. Yugoslavia), 33 STANFord Journal of International LAW 305, 325 (1997); Lador-Lederer, supra note 5, at 78 (describing the years 1914-1920 as the "great epoch" of the declaratory theory. He believes the declaratory theory dates back to a statement by U.S. President Monroe in 1823 regarding former European colonies); Quincy Wright, Some Thoughts About Recognition, 44 AmErICAN 
recognition is seen as mere acknowledgement of an already existing state of affairs. Recognition therefore has no direct bearing on the question whether an entity is a state or not; it simply establishes the fact that the recognizing state is prepared to conduct its relations with the recognised state on a state-to-state basis. Hershey, writing in 1927, simply states that "the State exists independently of its recognition." 13

The declaratory theory's success is due to the fact that is more consistent in its application. The constitutive theory has many inherent weaknesses, which are difficult to overcome. It is, for example, unclear what the status of an entity is that is recognised by some states, but not by others -is it a state only in relation to the recognising states? ${ }^{14}$ Furthermore, the constitutive theory poses the risk that realities are ignored. What is to become of a state-like entity that is simply not recognised by other states? Do international law rules apply to its conduct or to the conduct of other states toward it? There are no convincing and easy answers to these questions. ${ }^{15}$

Another major weakness of the constitutive theory is the leeway it grants already existing states in relation to emerging states. By declaring their statehood to be dependent on other states' recognition, they become subject to possibly abusive conditions which other states can impose. One of the alleged new conditions of statehood, "democratic" governance, points in that direction: after all, the ICJ has in the past declared that a state's political system is one of the issues it must be able to decide on its

Journal of International LAW 548, 557 (1950); CrawFord, supra note 7, at 22-26; Talmon, supra note 6, at 105-07; Steven Wheatley, Recognition and Secessionist [sic] in the Complex Environment of World Politics 3 (2013) (paper presented at the conference on "States falling apart? Secessionist and autonomy movements in Europe" (University of Fribourg, Switzerland, Aug. 2013)).

13 Amos S. Hershey, Essentials of International Public Law and Organization 199 (2d ed. 1927); William Edward Hall, A Treatise on INTERNATIONAL LAW 19-20 (8th ed. 1924).

14 Herbert W. Briggs, Community Interest in the Emergence of New States: The Problem of Recognition, 44 American Society of International Law Proceedings 169, 172 (1950) (“chaotic"); Crawford, supra note 7, at 20-21; Talmon, supra note 6, at 102; WheATLEY, supra note 12, at 3.

15 O'Brien, supra note 12, at 170-71; CraWford, supra note 7, at 20-21; Talmon, supra note 6, at 102-03. 
own, free from outside intervention. ${ }^{16}$ The constitutive theory, however, would enable precisely such an imposition.

The attempt by the modern proponents of the constitutive theory to solve these problems by imposing a duty on other states to recognise is not borne out by state practice. ${ }^{17}$ States have always and consistently insisted that they are the sole judge of whether an entity is to be recognised or not. ${ }^{18}$ In addition to these weaknesses, there is also little support for the constitutive theory in state practice and, especially, in opinio juris.

Attempts at combining both theories by, on the one hand, acknowledging that states cannot be created by other states' recognition while, on the other hand, claiming that a non-recognised entity cannot act as and therefore cannot be a state, ${ }^{19}$ fail to convince. Somaliland and Rhodesia are

16 Military and Paramilitary Activities in and against Nicaragua (Nicar. v. U.S.), Judgment, 1986 I.C.J. Rep. 14, 106, 202 (June 27); see also Armed Activities on Territory of Congo (Dem. Rep. Congo v. Uganda), Judgment, 2005 I.C.J. Rep. 168, 226, 99 161-165 (Dec. 19) [hereinafter ICJ Armed Activities on Congo].

17 Wright, supra note 12, at 548-49 (Quoting from a confidential UN Secretariat memorandum sent by the UN General Secretary to the President of the Security Council (Mar. 8, 1950): "[T] he practice of states shows that the act of recognition is ... decision which each State decides in accordance with its own free appreciation of the situation."); Briggs, supra note 14, at 171; Ruda, supra note 12, at 451; DuURSMA, supra note 12, at 115; Briggs, supra note 12, at 119; CRAWFORD, supra note 7, at 22; Talmon, supra note 6, at 103; DUgARD, supra note 3, at 49; Vidmar, supra note 10 , at 703 .

18 Briggs, supra note 14, at 180 (Responding to Syrian criticism of the U.S. recognition of Israel, the U.S. Ambassador to the UN, Austin, declared in May 1948: "I should regard it as highly improper for me to admit that any country on earth can question the sovereignty of the United States of America in the exercise of that high political act of recognition of the de facto status of a State. Moreover, I would not admit here, by implication or by direct answer, that there exists a tribunal of justices or of any other kind, anywhere, that can pass judgment upon the legality or validity of that act of my country."); Brown, supra note 3, at 621 .

19 Dugard, supra note 3, at 56, 58-60 (Claiming non-recognised entities cannot be states as they do not fulfil the fourth criterion of statehood, "capacity to enter into relations with other states." That view is problematic as Jelinek's Drei-ElementenLehre, followed by some states in their recognition policy, does not demand the fourth criterion. Furthermore, the criterion demands the "capacity to enter into," not the existence of relations with other states. Lastly, as outlined in the text, non- 
often cited as examples, because there is widespread agreement as to both entities fulfilling the criteria of statehood, while being universally unrecognised. ${ }^{20}$ However, at closer inspection, both states do not provide evidence of lacking statehood despite them being unrecognised. ${ }^{21}$ In the past Rhodesia was, of course, disadvantaged due to universal non-recognition. However, the entity was nevertheless treated as a state in the non-political sphere -hence the loans extended to the state by banks and the fact that there were low-level contacts with the Rhodesian government. ${ }^{22}$ Similarly, Somaliland, while not being recognised as such, nevertheless is treated as a state by many actors, including other states. This is evidenced by various memorandums of understanding the British government has signed with Somaliland, ${ }^{23}$ the fact that, for example, the German government has

recognised states usually do have relations with other states, albeit below the level of diplomatic relations.).

20 Dugard, supra note 3, at 58-59, 63-64.

21 Christian Marxsen, Territorial Integrity in International Law - Its Concept and Implications for Crimea, 75 ZEITSCHRIFT FÜR AUSLÄNDISCHES ÖFFENTLICHES ReCht Und VÖLKERRECHT 7, 13-14 (2015); Vidmar, supra note 10, at 736 (referring to the FRY and Macedonia).

22 On the flouting of the Rhodesian sanctions, see Joseph Mtisi et al., Social and Economic Developments During the UDI Period, in Becoming Zimbabwe 115, 133-36 (Brian Raftopoulos \& Alois Mlambo eds., 2009) (explaining certain states refused to ratify the sanctions (China, Bangladesh, and North Korea, as well as non-UN members - at that time-West Germany and Switzerland) while others, including France and Spain were reluctant to do so in order to help solve what they regarded as essentially a British problem. Economic dependency on Rhodesia meant that Malawi, Zambia, and Botswana never implemented the sanctions fully. Unsurprisingly, South Africa and Portuguese Mozambique ignored the sanctions altogether (Mozambique implementing them when the country gained its independence in 1975). The U.S. later deviated from the sanctions regime in order to import chrome from Rhodesia, while the oil embargo was violated by major petroleum companies, including British ones (with, it was later to transpire, the knowledge of the British government)). See Colin Stoneman, Zimbabwe's INHERITANCE 1, at 4, 6 (1981) (referring to the report resulting from the official UK government enquiry into the matter in the late 1970s).

23 See Freedom of Information Act 2000 Request Reference (2013), https:// www.gov.uk/government/uploads/system/uploads/attachment_data/file/356843/ 
been subsidizing Somaliland's courts, police forces and the prison system since $2008,{ }^{24}$ but also by many other diplomatic contacts Somaliland has managed to establish. ${ }^{25}$ There is also little doubt that many members of the international community would take a dim view of an attempt by the Somalian government to reassert its authority against Somaliland's wishes. Finally, Taiwan is a very good example disproving the aforementioned "compromise" theory. Despite not recognizing the island as a state, there is no doubt that most members of the international community treat Taiwan as a separate, independent state. ${ }^{26}$ So while a non-recognised state suffers disadvantages, it nevertheless benefits from some of the advantages of being a state. ${ }^{27}$ Lastly, the claim that Somalia contradicts the declaratory theory as it is still recognised as a state, despite no longer fulfilling the statehood criteria ${ }^{28}$ is similarly unconvincing. In describing such entities as "failed

Recognition_of_currently_unrecognised_country_of_the_Republic_of_ Somaliland_FOI_ref_0760-13.pdf (In 2007, the UK signed a memorandum of understanding on "immigration returns" with Somaliland and in 2013 on "aviation security," furthermore, the UK government has "close links" to the Somaliland Administration and Somaliland Ministers meet UK government representatives regularly.).

24 Rainer Stinner, Piratennetzwerke besser bekämpfen, Internationale Politik, May/June 2012, at 115-19, (especially at 115, 119); Dugard, supra note 3, at 179.

25 T.G., The Economist Explains: Why is Somaliland Not a Recognized State?, The Economist, (Nov. 1, 2015, 11:21 PM), http://www.economist.com/blogs/ economist-explains/2015/11/economist-explains.

26 Only 23 states have recognised Taiwan. Nevertheless, many other states have close, though unofficial relations to Taiwan. For example, U.S.-Taiwan relations are governed by the Taiwan Relations Act (93 Stat. 416 (1979); to be reaffirmed in 2016 by Congress (S. Con. Res 38, 114th Cong. (2015-2016), already passed by the Senate)); many states maintain "offices" in Taiwan's capital (though never referred to as Embassies), while Taiwan maintains "representative offices" in those states' capitals. Economic ties are close.

27 Hannes Hofmeister \& Belen Omos Giupponi, "Conscious Uncoupling” - Legal Aspects of Scot Independence in Autonomie und Selbstbestimmung in Europa Und im internationalen Vergleich 196, 205 (Peter Hilpold ed., 2016) (describing this situation as "de facto recognition"); Marxsen, supra note 21, at 14-15 (referring also to Taiwan).

DUGARD, supra note 3, at 59-60. 
states", the international community has acknowledged the loss of one or more statehood criteria. Somaliland and, possibly, Puntland aside, there is no other state that lays claim to sovereignty over Somalian territory, meaning a much weaker claim to statehood may well be sufficient. ${ }^{29}$

There is also support only for the declaratory theory as far as treaties are concerned: ${ }^{30}$ both Article 3 of the 1933 Convention on Rights and Duties of States (Montevideo Convention) ${ }^{31}$ and Article 9 of the 1948 Charter of the Organisation of American States ${ }^{32}$ support the declaratory theory.

The same applies to opinio juris: insofar it has been expressed, it has been in favour of the declaratory theory. ${ }^{33}$ In 1991, for example, the EC Arbitration Commission on Yugoslavia stated in its Opinion No. 1: “... the answer to this question should be based on the principles of public international law ... the existence or disappearance of the State is a question of fact; that the effects of recognition by other States are purely declaratory." ${ }^{34}$

As early as shortly after the First World War, commissions, tribunals, and courts expressed support for the declaratory theory. ${ }^{35}$ In 1920 the

29 Legal Status of East Greenland (Den. v. Nor.), Judgment, 1933 P.C.I.J. (ser. A/B) No. 5, at 46 (Apr. 5, 1933).

30 Talmon, supra note 6, at 106.

31 Convention on Rights and Duties of States art. 3, T.S. No. 881 (1933).

32 Charter of the Organization of American States art. 9, Apr. 30, 1948, 119 U.N.T.S. 47 (entered into force Dec. 13, 1951) (now art. 13 of the Organization of American States Charter, following the latest amendments of 1993).

33 Lador-Lederer, supra note 5, at 80 (a British government note to the UN dated Aug. 24, 1948) ("The existence of a State should not be regarded as depending upon its recognition but on whether in fact it fulfils the conditions which create a duty for recognition.") (the British view expressed here seems to be a mix between the declaratory theory and Lauterpacht's assumption of a duty to recognise); e.g., Talmon, supra note 6, at 106.

34 European Community Arbitration Commission on International Conference for Peace in Yugoslavia, Opinion No. 1, Aug. 27, 1991, 31 I.L.M. 1494 [hereinafter EC Arbitration in Yugoslavia]; for more details on the Badinter Commission's views, see Talmon, supra note 6, at 106-07.

35 Talmon, supra note 6, at 105-06 (first citing Institut de Droit International: Resolutions Concerning the Recognition of New States and New Governments, 30 American Journal of International Law, 185 (No. 4 Supp. 1936); and then citing Convention on Rights and Duties of States art. 3, T.S. No. 881 (1933)). 
International Committee of Jurists, when dealing with the Aaland question for the League of Nations, declared regarding Finland that, despite it being recognised by many other states as a state, this did not "suffice to prove that Finland, from this time onwards, became a sovereign state". ${ }^{36}$ This amounted to an implicit rejection of the constitutive theory. In 1929 the German-Polish Mixed Arbitral Tribunal in Deutsche Continental GasGesellschaft v. Poland stated that "the recognition of a state is not constitutive but merely declaratory. The state exits by itself and the recognition is nothing else than a declaration of this existence." ${ }^{37}$

Although dealing with the recognition of governments, the decision in the Tinoco Arbitration is also frequently cited as evidencing the prevalence of the declaratory theory. ${ }^{38}$ Taft CJ stated that "Such non-recognition for any reason...cannot outweigh the evidence disclosed... as to the de facto character of Tinoco's government, according to the standard set by international law." 39

State practice, on the other hand, has never been entirely consistent. There clearly have been cases in the past where the act of recognition has not only been declaratory in its effects. Nevertheless, even in these cases, such "constitutive" recognitions very often have been accompanied by statements describing the act of recognition as "declaratory", ${ }^{40}$ which in

36 Report of the International Committee of Jurists Entrusted by the Council of the League of Nations with the Task of Giving an Advisory Opinion upon the Legal Aspects of the Aaland Islands Question, LeAgue of Nations Official Journal 8 (Spec. Supp. No. 3 1920) [hereinafter Aaland Islands Question]; Lador-Lederer, supra note 5, at 81 (mentioning the support for the declaratory theory expressed by the International Commission of American Jurists in 1927).

37 Deutsche Continental Gas-Gesellschaft v. Poland, 5 Ann. Dig. 11, 15 (Ger.-Pol. 1929).

38 O'BRIEN, supra note 12, at 171.

39 Tinoco Arbitration (Gr. Brit. v. Costa Rica), 18 American Journal of InTERNATIONAL LAW 147, 154 (1924) (Taft, C.J., was the sole arbitrator).

40 EC Arbitration in Yugoslavia, supra note 34 (a prime example is the recognition of Bosnia and Herzegovina on April 7, 1992, by EC member states. It is generally agreed that this recognition was not merely declaratory, as that country's government had no control over its territory, at times not even of the capital city. On April 11, 1992, President Izetbegovic had to ask for outside help. Nevertheless, the EC maintained that the recognition of states was "declaratory" in nature.). 
turn implies that states felt the necessity to claim conformity to a rule they believed was binding.

In summary, customary international law on state recognition declares that the recognition extended by another state is merely declaratory of the fact that an entity is already a state. But what criteria have been established in customary international law for judging whether an entity has become a state?

\section{b. Criteria of Statehood}

Article 1 of the 1933 Convention on Rights and Duties of States (Montevideo Convention), enumerated these criteria as follows: 1) "permanent population", 2) “defined territory", 3) "government", and 4) "capacity to enter into relations with other states". ${ }^{41}$

These so-called "Montevideo-criteria" were a reflection of state practice and opinio juris regarding statehood when the Montevideo Convention was concluded in 1933, notwithstanding the fact that the convention only ever applied in the Americas. ${ }^{42}$ Already in 1874, Woolsey had defined statehood as follows:

A state is a community of persons living within certain limits of territory, under a permanent organization, which aims to secure the prevalence of justice under self-imposed $\operatorname{law}^{43}$...It must have an exclusive right to impose laws within its territor $y^{44}, \ldots$ For the purposes of international law that state can only be regarded as sovereign, which has retained its power to enter into all relations with foreign states... ${ }^{45}$

In 1929 the German-Polish Mixed Arbitral Tribunal in Deutsche Continental Gas-Gesellschaft v. Poland declared that a state "does not exist unless

41 Montevideo Convention on the Rights and Duties of States, Dec. 26, 1933, 165 L.N.T.S. 19 (entered into force Dec. 26, 1934) [hereinafter Montevideo Convention].

42 Thomas D. Grant, Defining Statehood: The Montevideo Convention and its Discontents, 37 Columbia Journal of Transnational LaW 403, 414-18 (1999).

43 Theodore D. Woolsey, Introduction to the Study of International LaW Designed as an Aid to Teaching, and in Historical Studies, $\$ 36$ (4th ed. rev. and enlarged 1874).

$44 \quad I d . \$ 37$.

45 Id. 
it fulfils the conditions of possessing a territory, a people inhabiting that territory, and a public power which is exercised over the people and the territory." 46

This definition is more or less identical to Jelinek's "Drei-ElementenLehre," which he had developed and publicized by $1900 .{ }^{47}$ The difference to "Montevideo" is simply that its proponents argue that the "capacity to enter into relations with other states" is an element of the third criteria, "government." 48

By the 1930s and 1940s, there was also widespread academic support for the "Montevideo criteria" ${ }^{49}$ The Permanent Mandates Commission of the League of Nations applied similar criteria, which the Council of

46 Deutsche Continental Gas-Gesellschaft v. Poland, 5 Ann. Dig. at 15.

47 Talmon, supra note 6, at 109-10.

48 BAER, supra note 12, at 50-51; Peter Hilpold, Völkerrechtsprobleme um Makedonien, 42 Recht in Ost und West 117, 121 (1998). But see Talmon, supra note 6, at 116-17 (Talmon is a supporter of Jelinek's Drei-Elementen-Lehre. However, he believes the criterion of "capacity to enter into relations with other states" is a criterion of recognition, not of statehood, notwithstanding "some" states' declarations to the contrary.).

49 T. J. Lawrence, The Principles of International Law 85 (Winfield ed., 7th rev. ed. 1923) ("The community thus recognized must, of course, possess a fixed territory, within which an organised government rules in civilized fashion, commanding the obedience of its citizens and speaking with authority on their behalf in its dealings with other states."); HALL, supra note 13, at 19-20 (defining states as follows: "The simple facts that a community in its collective capacity exercises undisputed and exclusive control over all persons and things within the territory occupied by it, that it regulates its external conduct independently of the will of any other community, and in the conformity with the dictates of international law, and finally that it gives reason to expect that its existence will be permanent, are sufficient to render it a person in law."); Hershey, supra note 13, at 158-59 (enumerating the "essential characteristics of a State" as follows: "(1) A people permanently organised for political purposes ... (2) A definite territory ... (3) A certain degree of sovereignty ... and a government that is habitually obeyed."); Briggs, supra note 14, at 171; Grant, supra note 42, at 414-18; Brown, supra note 3, at 620-21 (citing the Institut de Droit International's 1936 resolution: "The recognition of a new state is the free act by which one or several states take note of the existence of a human society, politically organised on a fixed territory, independent of any other existing state, capable of observing the prescriptions of 
the League of Nations subsequently approved, when deciding whether the British Mandate of Mesopotamia had truly become the independent Kingdom of Iraq by $1931 .^{50}$

In the 1970s and 1980s the US ${ }^{51}$ and British ${ }^{52}$ governments were still officially basing their decisions on recognition on the "Montevideo" criteria. The Israeli Ministry of Foreign Affairs declared in response to a

international law and thus indicating their intention to consider it a member of the international community.").

5012 League of Nations Official Journal 2044, 2057 (1931) (approving the Permanent Mandates Commission's opinion of September 1931, which enumerates the following prerequisites regarding the termination of a mandate (it examined the issue in connection with Iraq's prospective independence): (a) "settled government and an administration capable of maintaining the regular operation of essential government services"; (b) "capable of maintaining its territorial integrity and political independence"; (c) "able to maintain the public peace throughout its territory"; (d) "adequate financial resources"; and (e) "laws and a judicial organization.").

51 U.S. Department of State, Statement, reprinted in 72 American Journal of International Law 337 (1978); Alison K. Eggers, When is a State a State? The Case for the Recognition of Somaliland, 30 Boston College International and Comparative Law Review 211, 214 (2007) (contending that the U.S. practice has been "fairly consistent" in that respect).

52 Alice Lacourt, Legal Advisor, UK Foreign and Commonwealth Office, The Approach of the United Kingdom, Address at the Chatham House International Law Discussion Group Meeting: The Approach of the United Kingdom (Apr. 22, 2008), https://www.chathamhouse.org/sites/files/chathamhouse/public/ Research/International\%20Law/il220408.pdf (declaring the following: "When deciding whether to recognise Kosovo the United Kingdom had applied the criteria set out in 1989 by the then Parliamentary Under-Secretary for Foreign and Commonwealth Affairs, Mr. Sainsbury, in a Written Answer dated 16 November. Mr. Sainsbury had said that: 'The normal criteria that we apply for recognition as a state are that it should have, and seem likely to continue to have, a clearly defined territory with a population, a Government who are able of themselves to exercise effective control of that territory, and independence in their external relations. Other factors, including some United Nations resolutions, may also be relevant."'); Colin Warbrick, Recognition of States, 41 InTERNATIONAL AND Comparative LaW Quarterly 473, 473 (1992) (making the point that British practice has mostly adhered to these guidelines). 
possible unilateral declaration of independence by the Palestinians after May 4, 1999:

International law has established a number of criteria for the existence of a state: effective and independent governmental control, possession of defined territory; the capacity to freely engage in foreign relations; and control over a permanent population. ${ }^{53}$

Even nowadays it is still widely held that these criteria reflect the core criteria of statehood, even if some view them as not exhaustive. ${ }^{54}$ States have consistently demonstrated a great reluctance to depart from the Montevideo criteria of statehood. Although, as the ICJ pointed out, not directly relevant to the advisory opinion requested, Japan, ${ }^{55}$ Germany, ${ }^{56}$

53 May 4, 1999 -Some Frequently Asked Questions, Israeli Ministri of Foreign AfFAirs, http://www.mfa.gov.il/MFA/MFAArchive/1990_1999/1999/4/May+4+1999+-+Some+Frequently+Asked+Questions+-+19.htm.

54 Bengt Broms, States, in International Law: Achievements and Prospects 41, 43-44 (Mohammed Bedjaoui ed., 1991); Charlesworth \& Chinkin, supra note 12, at 125-26; Rich, supra note 5, at 55; DuUrsma, supra note 12, at 112; CRAWFORD, supra note 7, at 45-46 (although he does argue for some variations); Talmon, supra note 6, at 109-11, 125; DugARD, supra note 3, at 26-27.

55 ICJ Self-Government of Kosovo, supra note 2; Accordance with International Law of the Unilateral Declaration of Independence in Respect of Kosovo, Written Statement of Japan (Apr. 17, 2009), http://www.icj-cij.org/docket/files/141/15658. pdf ("For the formation of a State, international law generally requires that an entity shall meet the conditions of statehood, namely an entity holds an effective government which governs a permanent population within a defined territory.").

56 ICJ Self-Government of Kosovo, supra note 2; Accordance with International Law of the Unilateral Declaration of Independence in Respect of Kosovo, Written Statement of Germany (Apr. 15, 2009), http://www.icj-cij.org/docket/ files/141/15624.pdf ("Thus, international law sets certain conditions that must be present before a newly self-declared state may be recognised by other states, viz., the three elements of statehood: a territory, a people and effective government."). 
Norway, ${ }^{57}$ and the USA ${ }^{58}$ used the opportunity to confirm the applicability of the traditional criteria of statehood in their written statements to the court of 2009, as did the UK in 2008. ${ }^{59}$

Generally, there is also agreement, as far as the content of the four statehood criteria are concerned:

"Permanent population" refers to an undefined number of people living permanently in a specific area. In existing states, nationality makes the relevant group of people easily identifiable. However, nationals need not even form the majority within the population. There is no minimum number required, and the group of people living in the entity do not necessarily have to be bound to each other by race, religion, or culture. The population must, however, form a stable community. ${ }^{60}$

"Defined territory" requires a specific area in which the entity can exercise what is commonly regarded as the functions of state to the exclusion of others. Based on state practice, it is assumed that border disputes do not

57 ICJ Self-Government of Kosovo, supra note 2; Accordance with International Law of the Unilateral Declaration of Independence in Respect of Kosovo, Written Statement of Norway (Apr. 16, 2009), http://www.icj-cij.org/docket/files/141/15650. pdf ("Nevertheless, as regards international law, the existence of statehood is a question of fact relying on an assessment of constitutive elements including a defined territory, permanent population, effective government and legal capacity to enter into relations with the other states.").

58 ICJ Self-Government of Kosovo, supra note 2; Accordance with International Law of the Unilateral Declaration of Independence in Respect of Kosovo, Written Statement of the United States of America (Apr. 17, 2009), http://www.icj-cij. org/docket/files/141/15640.pdf (“Second, based on its assessment of Kosovo's development during the period of UNMIK administration, the United States was satisfied that Kosovo's viability as a state was not in doubt and that it met the criteria of statehood outlined in Article 1 of the 1933 Montevideo Convention.... Consideration of these criteria had likewise been a cornerstone of U.S. recognition of other states seeking independence in the former Yugoslavia in the early 1990s.”).

59 See supra text accompanying note 52.

60 Duursma, supra note 12, at 117; Charlesworth \& Chinkin, supra note 12, at 126-28; Broms, supra note 54, at 44; CRAWFORD, supra note 7, at 52-55. 
usually impair an entity's recognition as a state, but that an undisputed core of territory is required. ${ }^{61}$

"Government" is generally assumed to mean "effective government." It is widely seen as the most important and most contentious criterion. The entity's leadership must be able to enforce law and order, and guarantee a certain degree of stability within a given area. Within that territory, the entity's state organs must be able to govern effectively, if possible based on some organizational structure, without having to resort to third parties. ${ }^{62}$

"Capacity to enter into relations with other states" mainly requires the entity to be able to conduct its foreign relations independently without having to take recourse to another state. State practice implies that formal independence (independence in the legal sense) is sufficient. "Real" independence, meaning economic or military independence, is not necessary. ${ }^{63}$ As already pointed out, proponents of Jelinek's theory argue that a government is only "effective", if it can conduct its foreign affairs independently, so this is not a criterion which is examined separately.

Needless to say, these criteria have been heavily criticized over the years. Some have argued that the fourth criterion is contradictory, as that capacity is a consequence, not a prerequisite of being a state. ${ }^{64}$ This is not convincing. The fourth criterion, of course, does require a prognosis when a new state emerges. There is, however, no reason why such a prognosis

61 Duursma, supra note 12, at 116-17; ChARlesworth \& Chinkin, supra note 12, at 128-32; Broms, supra note 54, at 44; Hilpold, supra note 48, at 121; CrAWfORD, supra note 7 , at $46-52$.

62 Duursma, supra note 12, at 118-20; Charlesworth \& Chinkin, supra note 12, at 132-33; BAER, supra note 12, at 49-50; Broms, supra note 54, at 44-45; Hilpold, supra note 48, at 121; Danilo Türk, The Dangers of Failed States and a Failed Peace in the Post Cold War World, 27 New York University Journal of International Law and Politics 625, 625-26 (1995); Crawford, supra note 7, at 55-62; Talmon, supra note 6, at 110-11.

63 Duursma, supra note 12, at 120-27; Charlesworth \& Chinkin, supra note 12, at 133-35; Talmon, supra note 6, at 111-16.

64 See, e.g., Talmon, supra note 6, at 116-17. 
should not be possible. If an entity will not be able to enter into international relations independently, it will not become a state.

\section{c. Are There Further Criteria of Statehood?}

Some have argued that "actual independence" is necessary if an entity is to obtain statehood. ${ }^{65}$ Not only is the definition of "actual independence" highly contentious, but the notion is also not supported by state practice. Many smaller states that have been recognised as such by the international community are far from having attained anything like "actual independence." 66 States in the Pacific, like Palau, or even in Europe, like Monaco, are completely or partly dependent on other states for their survival. Such states may be regarded as anomalies. Nevertheless, international recognition of their statehood implies that "actual" independence is not required in order to obtain statehood. Even proponents of the criterion of "actual" independence admit that the requirement is often "hollow" in practice. ${ }^{67}$

Many, especially in recent years, have also argued that further criteria have been added to the "Montevideo list". ${ }^{68}$ Respect for human rights and democratic government are two of the many additional criteria that are now supposedly decisive in obtaining statehood ${ }^{69}$ It is, however, extremely doubtful whether opinio juris and, especially, state practice have been consistent enough to have led to changes in customary international law. ${ }^{70}$ This

65 Grant, supra note 12, at 312; CRAWFORD, supra note 7, at 72-89.

66 Grant, supra note 42, at 438-39; Talmon, supra note 6, at 111-16 (providing many examples of state practice which evidence that "factual" independence is not seen as a prerequisite of statehood).

67 CRAWFORD, supra note 7, at 88 (admitting there are cases where the criteria of "actual independence" can have "minimal content").

68 Dugard, supra note 3, at 52-55.

69 GRANT, supra note 3, at 83-119; Talmon, supra note 6, at 121-26; Vidmar, supra note 10 , at 704, 710-34, 743-47 (claiming that in cases of secession either the parent's state waiver as far as its territorial integrity or a consensus between the parent state and the new state is a further requirement of statehood).

70 Certainly, it seems very doubtful that additional criteria like democracy had been established in international law by even the early 1990s. The EC's handling of the recognition of the new states emerging from the former Soviet Union 
is especially true when considering that states have always tried to impose varying conditions on new states in return for recognition without any of these criteria ever having been applied consistently.

Already in the early $19^{\text {th }}$ century, the United Kingdom demanded the abolition of the slave trade as a precondition of recognizing Mexico and Brazil. ${ }^{71}$ In 1878, the Congress of Berlin made its participants' recognition of Bulgaria, Serbia, Montenegro and Romania dependent on them undertaking certain measures to protect religious minorities within their territories. ${ }^{72}$ The USA made its recognition of Egypt and Albania dependent on commercial concessions. ${ }^{73}$ The international community's hesitation in recognizing Guinea-Bissau has been attributed to its lack of a democratically legitimized government. ${ }^{74}$

However, the main impetus for arguing that international law now demands additional criteria of statehood was provided by the EC's reaction to the break-up of the Soviet Union and Yugoslavia. On 16 December 1991, the EC issued its "Declaration on the 'Guidelines on the recognition of New States in Eastern Europe and in the Soviet Union"” ${ }^{75}$ While explicitly emphasizing the EC's adherence to "normal standards of international

and Yugoslavia in 1991/1992 is a case in point. Hannum, supra note 3, at 64, 69 (describing that "attempting to create a new rule of international law," an attempt he views as "laudable," but "having failed"); Weller, supra note 3, at 588 (arguing that the EC's "extensive catalogue of criteria" evidenced that "general international law" was not being applied); Crawford, supra note 7, at 148, 150-55; Martti Koskenniemi, National Self-Determination Today: Problems of Legal Theory and Practice, 43 International \& Comparative Law Quarterly 241, 264-69 (1994) (believing that the rules governing recognition of new states emerging on the territory of the former Yugoslavia and their application in practice were based more on "political priorities" than on legal considerations); see also supra notes 55-58 (indicating that at least these states do not apply additional legal criteria when deciding whether to a new state); Talmon, supra note 6, at 121-26.

71 Rein Müllerson, International Law, Rights and Politics 134 (1994).

72 Id.; BAER, supra note 12, at 332.

73 BAER, supra note 12, at 332.

74 Grant, supra note 42, at 442. But see BAER, supra note 12, at 410-11 (arguing that delayed recognition was more likely due to the government's lack of effectiveness).

75 Declaration on the "Guidelines on the Recognition of New States in Eastern Europe and in the Soviet Union,” December 16, 1991, 31 I.L.M. 1486-87 (1992). 
practice" ${ }^{76}$ the guidelines seemed to impose numerous conditions on new states traditionally not viewed as preconditions for recognition. As far as the Soviet Union was concerned, new states, wishing to be recognised, had to adhere, among other things, to the UN Charter, the Final Act of Helsinki and the Treaty of Paris, "especially with regard to the rule of law, democracy and human rights". ${ }^{77}$ The "Declaration on Yugoslavia"78 was even more onerous: new states had to "accept the provisions laid down in the draft Convention especially...on human rights and rights of national or ethnic groups under consideration by the Conference on Yugoslavia", had to guarantee that "no territorial claims against a neighbouring Community State" existed, and refrain from "hostile propaganda...against a Community State" ${ }^{79}$

On the face of it, it would seem that a major group of states, comprising 12 members including such relatively powerful states, such as the United Kingdom, Germany, France, Italy, and Spain were indeed attempting to create new rules on recognition in international law. However, neither did the international community as a whole apply these additional criteria to the recognition of new states, nor did the EC truly attempt to implement their guidelines.

The USA recognised all of the former Soviet Republics as independent states on 25 December 1991, although refraining to establish diplomatic relations with six of them until it was satisfied they had made "commitments to...democratic principles" which seriously undermines the claim new customary international law was created. Furthermore, to describe states such as Kyrgyzstan, Tajikistan, or Uzbekistan as being at any time or in any way democratic - as understood in western states - is fanciful. Nevertheless, the EC had extended recognition to all these states by midJanuary 1992. The EC itself therefore never applied any additional criteria when recognizing these states beyond demanding written assurances that were never evaluated in any way. ${ }^{80}$ There is nothing to suggest that states such as China, Russia, India or Brazil apply any of these additional criteria

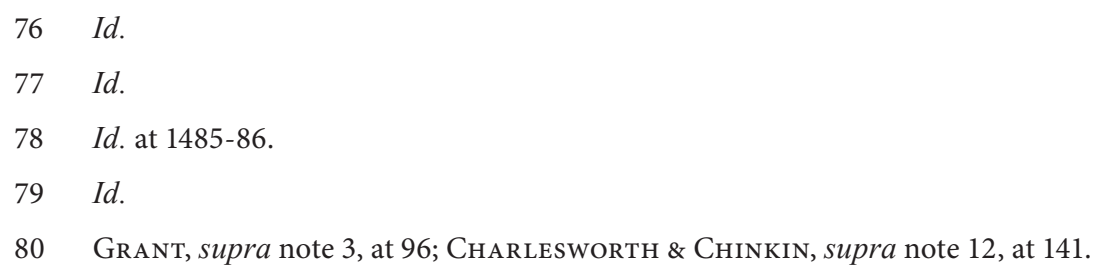


when deciding whether to recognise an entity as a new state. There is also no evidence of an in-depth assessment by the international community of Eritrea's and South Sudan's democratic credentials when extending recognition in 1993 and 2011 respectively.

Lastly, claiming that concepts such as "democratic principles" could be an additional statehood criterion is far from helpful in clarifying the law on statehood due to their extremely controversial and therefore hazy content. Rather, such theories provide states yet more excuses to interfere in other states' internal affairs. As the ICJ has explained this may well violate the principle of non-intervention:

A prohibited intervention must accordingly be one bearing on matters in which each State is permitted, by the principle of State sovereignty to decide freely. One of these is the choice of a political, economic, social and cultural system, and the formulation of foreign policy. Intervention is wrongful when it uses methods of coercion in regard to such choices, which must remain free ones... ${ }^{81}$

It seems some states are attempting to circumvent this clear dictum by indicating that a non-democratic state is not a state at all - a far-fetched, unhistorical idea, but reminiscent of $19^{\text {th }}$ century thinking, when a group of existing states claimed the privilege to decide which entity was to be admitted to the "family of nations".

In summary, based on state practice, it is safe to say that no new criteria have been established in international law when judging whether an entity has become a state.

\section{PRINCIPLE OF NON-RECOGNITION}

However, the international community sometimes decides not to recognise a state that meets the aforementioned criteria. ${ }^{82}$ State practice evidences two cases when states are regularly not recognised: (a) states where the

81 Military and Paramilitary Activities in and Against Nicaragua (Nicar. v. U.S.), Judgment, 1986 I.C.J. Rep. 14, g 205 (June 27).

82 See Talmon, supra note 6, at 101-81, for a very detailed examination of the principle of non-recognition. See also id. at 122-53 (believing that states thus not recognised nevertheless meet the criteria of statehood, and that their non-recognition must be viewed as "withholding from a state its legal status"); DugARD, supra note 3, at $81-85$. 
principle of internal self-determination is violated fragrantly, ${ }^{83}$ and (b) states that were created by the illegal use of force. ${ }^{84}$ The ICJ has confirmed the legal validity of these two forms of collective non-recognition. ${ }^{85}$

\section{a. Non-Recognition Based on Violations of Internal Self-Determination}

Not recognizing a state due to its lack of internal self-determination is a principle that has only developed into a legal obligation since WWII. ${ }^{86}$ As pointed out by the International Court of Justice, prior to that the principle of self-determination had become a political, but not yet a legal principle. ${ }^{87}$

It is true that US President Wilson had outlined his vision of national self-determination when he declared, in an address to the League to Enforce Peace in 1916, "that every people has a right to choose the sovereignty under which they shall live." He emphasized his beliefs when he added that "no peace can last or ought to last which does not accept the principle that governments derive all their just powers from the consent of the governed", and that "no right anywhere exists to hand peoples about from sovereignty to sovereignty as if they were property." ${ }^{88}$ In his address to a Joint Session of Congress in January 1918 President Wilson then announced his famous "Fourteen Points", which he deemed to be the "only possible program" for the "world's peace". ${ }^{89}$ The principle upon which his "Fourteen Points" were

83 Hillgruber, supra note 10, at 505-07; Talmon, supra note 6, at 122-24, 146-47, 171-79; Dugard, supra note 3, at 28-29, 81-85.

84 O'Brien, supra note 12, at 185; Grant, supra note 12, at 314; Talmon, supra note 6, at 124, 144-46, 171-79; Dugard, supra note 3, at 27-28, 81-85.

85 ICJ Self-Government of Kosovo, supra note 2, 981.

86 CraWford, supra note 7, at 433.

87 ICJ Self-Government of Kosovo, supra note 2, g9 79, 82 (pointing out that the right of self-determination had "evolved" only in the "second half of the twentieth century"); see Aaland Islands Question, supra note 36, for a legal analysis of the situation in 1920.

88 Self-Determination - Civil War and Imperialism, Encyclopedia of the New American Nation, http://www.americanforeignrelations.com/O-W/SelfDetermination-Civil-war-and-imperialism.html.

89 President Wilson's Fourteen Points, World War I Document Archive, http://wwi.lib.byu.edu/index.php/President_Wilson\%27s_Fourteen_Points (last modified Feb. 28, 2008). 
based was described by Wilson as "the principle of justice to all peoples and nationalities, and their right to live on equal terms of liberty and safety with one another, whether they be strong or weak" ${ }^{90}$ Mention must also be made of Lenin's Decree on Peace of October 26, 1917, which was even more far-reaching as far as the concept of self-determination was concerned:

By annexation or seizure of foreign territory the government, in accordance with the legal concepts of democracy in general and of the working class in particular, understands any incorporation of a small and weak nationality by a large and powerful state without a clear, definite and voluntary expression of agreement and desire by the weak nationality, regardless of the time when such forcible incorporation took place, regardless also of how developed or how backward is the nation forcibly attached or forcibly detained within the frontiers of the [larger] state, and, finally, regardless of whether or not this large nation is located in Europe or in distant lands beyond the seas... ${ }^{91}$

Nevertheless, the 1920 statement by the International Commission of Jurists, reporting on the Aaland Island issue, remained correct until after the end of WWII:

Although the principle of self-determination of peoples plays an important role in modern political thought, especially since the Great War, it must be pointed out that there is no mention of it in the Covenant of the League of Nations. The recognition of this principle in a certain number of treaties cannot be considered as sufficient to put it upon the same footing as a positive rule of the Law of Nations. ${ }^{92}$

Although the jurists, in their subsequent examination of the principle, did allow for the possibility of specific exceptions to this categorical statement, ${ }^{93}$ the lack of any mention of "self-determination" in the text of the Covenant

$90 \quad I d$.

91 The Decree on Peace, November 1917, The History Guide, http://www. historyguide.org/europe/decree.html (last modified April 13, 2012) (emphases added); see Bill Bowring, The Degradation of the International Legal Order?: The Rehabilitation of Law and the Possibility of Politics 1320, (2008); Antony Anghie, Imperialism, Sovereignty and the Making of INTERNATIONAL LAW 139 (2005).

92 Aaland Islands Question, supra note 36, at 5.

93 Id. at 5-6; Koskenniemi, supra note 70, at 246-47. 
of the League of Nations proves that the jurists' conclusion was fundamentally correct. ${ }^{94}$ The principle of self-determination was subsequently included in the Atlantic Charter of $1941^{95}$ and in the UN Charter of $1945,{ }^{96}$ but this cannot obscure the fact that its legal content was still ill defined (even nowadays some dispute it has any legal content). ${ }^{97}$

General Assembly resolutions providing definitions that were more precise were only passed in the 1960s. ${ }^{98}$ Regarding the recognition of states there is no evidence of any state practice or opinio juris that had established the connection between self-determination and non-recognition by then. It had certainly not yet established itself as a rule of customary international law. ${ }^{99}$ However, this changed during the decolonisation process. Progress in the sphere of civil and political rights and, more generally, in the field

94 It could be argued that the mandate system, introduced in art. 22 of the Covenant of the League of Nations, to some extent was a (weak) reflection of the principle of self-determination as it at least claimed to be preparing the peoples in the mandated territories for independence sometime in the future; Eugenia LópezJacoiste, Autonomy and Self-determination in Spain: Catalonia's Claims for Independence From the Perspective of International Law, in Аutonomie Und Selbstbestimmung in Europa und im internationalen Vergleich 218, 218 (Peter Hilpold ed., 2016).

95 See Joint Declaration by the President and the Prime Minister, U.K.-U.S., art. 2-3, Aug. 14, 1941, 55 Stat. 1603.

96 U.N. Charter art. 1, g 2.

97 ICJ Self-Government of Kosovo, supra note 2, g9 79, 82; CraWford, supra note 7, at 427, 433; L.C. Green, Self-Determination and Settlement of the Arab-Israeli Conflict, 65 American Society of International Law Proceedings 40, 43-44 (1971) (arguing that self-determination, as understood in the Charter, only refers to "nations"); see also id. at 46 (writing in 1971, claiming that there was still no right of self-determination in international law); Eli Murlakov, Das Recht Der Völker auf Selbstbestimmung im isRaelisch-ARA bischen Konflikt 86 (1983); Weller, supra note 3, at 592 (stating that the EC Arbitration Commission on Yugoslavia even in 1991/1992 "[f] ound that in actual practice international law did not define the precise consequences of that right or its scope of application"); Hofmeister \& Giupponi, supra note 27, at 203.

98 G.A. Res. 1514 (XV) (Dec. 14, 1960); G.A. Res. 2200 (XXI) (Dec. 16, 1966); G.A. Res. 2625 (XXV) (Oct. 24, 1970).

99 Grant, supra note 3, at 92. 
of human rights, was made. Many new states, which had only just joined the United Nations, were extremely anxious to safeguard their new status as independent states against any attempt at encroachment. ${ }^{100}$ The principle of self-determination, included in Article 1(2) UN Charter, was the obvious anchor of any attempt to safeguard developing states' new-found independence in international law against external interference. ${ }^{101}$ In this struggle, the newly independent states were massively supported by the Soviet Union.

The progression of a mere principle of self-determination to a right of self-determination was confirmed by the two covenants, the ICCPR and the ICESR;102 common Article 1 states: "All peoples have the right of self-determination. By virtue of that right they freely determine their political status and freely pursue their economic, social and cultural development." 103

This was a confirmation of the view already taken by the General Assembly in its 1960 Resolution on the Granting of Independence to Colonial Countries and Peoples. ${ }^{104}$ It follows that the ICJ has repeatedly reaffirmed

100 Louise Doswald-Beck, The Legal Validity of Military Intervention by Invitation of the Government, 56 British Yearbook of International Law 189, 209-11, 252 (1985); John A. Perkins, The Right of Counterintervention, 17 Georgia Journal of International and Comparative Law 171, 189 (1987); Michel Krauss, Internal Conflicts and Foreign States: In Search of the State of Law, 5 Yale Studies in World Public Order 173, 212-13 (1980).

101 Sherle R. Schwenninger, The 1980s: New Doctrines of Intervention or New Norms of Nonintervention?, 33 Rutgers Law Review 423, 428-29 (1981); Josef Rohlik, Some Remarks on Self-Defense and Intervention: A Reaction to Reading Law and Civil War in the Modern World, 6 Georgia Journal of International and Comparative Law 395, 406 (1976); Perkins, supra note 100, at 185.

102 Dugard, supra note 3, at 90-94.

103 International Covenant on Civil and Political Rights art. 1, Dec. 16, 1966, 999 U.N.T.S. 171; International Covenant on Economic, Social, and Cultural Rights art. 1, Dec. 16, 1966, 993 U.N.T.S. 3.

104 G.A. Res. 1514 (XV) (Dec. 14, 1960); Eckart Klein, Nationale Befreiungskämpfe und Dekolonisierungs-Politik der Vereinten Nationen: Zu einigen Völkerrechtlichen Tendenzen, 36 ZeItschrift FÜR AUSLÄNDISChes ÖFFENTLICHES RECHT UND VölKerRecht 618, 641 (1976). 
the existence of a right of self-determination and has even conferred an erga omnes character on it. ${ }^{105}$

This development did have its effect on customary international law governing the recognition of states. It led to the recognition of many new states during decolonisation. But it also created a bar to recognition. In 1965 the Rhodesian government, which formally was still a British colony, issued a unilateral declaration of independence (UDI) from the United Kingdom, aimed at resisting the implementation of black-majority rule, that had occurred elsewhere in Africa, including the neighbouring states of Zambia (formerly Northern Rhodesia) and Malawi (formerly Nyasaland). ${ }^{106}$ Both the General Assembly and the Security Council expressed support for the liberation struggle of the black majority, affirming the right of selfdetermination for the Zimbabwean people, and exhorting Britain, as the administering power, to do all it could to topple the Rhodesian regime. ${ }^{107}$ United Nations member states were repeatedly enjoined not to recognise the regime or to aid its survival in any way. ${ }^{108}$ Although it is not seriously disputed that Rhodesia fulfilled all the necessary criteria of statehood, not one state recognised the country's independence until majority rule was established in 1980.

Similarly, Transkei, Ciskei, and other "homelands", created by the apartheid regime in South Africa for its majority black population, prob-

105 East Timor (Port. v. Austl.), Judgment, 1995 I.C.J. Rep. 90, 29 (June 30); Legal Consequences of Construction of a Wall in Occupied Palestinian Territory, Advisory Opinion, 2004 I.C.J. Rep. 136, 156 (July 4).

106 All three states having formerly been united in the Federation of Rhodesia and Nyasaland (also known as the Central African Federation), created by Britain in 1953 and dissolved, in the face of mounting internal opposition, ten years later.

107 G.A. Res. 2652 (XXV), 7 (Dec. 3, 1970) (The General Assembly urged the UK to use force to remove the UDI regime. The British government of Harold Wilson, however, although acting swiftly to impose trade and economic sanctions on Rhodesia following UDI, resiled from taking this ultimate step.).

108 S.C. Res. 216, 2 (Nov. 12, 1965) (a point made in the UN Security Council's first resolution on the matter, passed the day after the Unilateral Declaration was issued, calling on member states "not to recognise this illegal racist minority regime in Southern Rhodesia and to refrain from rendering any assistance to this illegal regime"). ; see also S.C. Res. 217 (Nov. 20, 1965). 
ably met the statehood criteria. ${ }^{109}$ However, the creation of these "Bantustans" was widely seen as an attempt by South Africa to rid itself of its black majority. Thus the creation of these states was widely condemned as a violation of the right of self-determination, ${ }^{110}$ so that only South Africa ever recognised the "homelands" as independent states.

Since the 1960s therefore the creation of a state that amounts to a denial of self-determination demands that state's non-recognition. However, the principle of non-recognition of states created by illegal force had already been developing prior to the Second World War and has been applied repeatedly since.

\section{b. Non-Recognition Based on the Illegal Use of Force}

Beginning in the 1930s state practice began to develop which supported the principle that changes brought about by states by illegal use of force should not be recognised. ${ }^{111}$ This principle is often referred to as the "StimsonDoctrine", named after the US Secretary of State who is credited with being the first to articulate it. In response to the invasion of the Chinese province of Manchuria by Japan in violation of its treaty obligations, and the subsequent creation of the independent state of Manchukuo by the Japanese, Stimson stated in a note to the US Ambassador in Japan of January 7, 1932:

... it [the United States' government] does not intend to recognize any situation, treaty, or agreement which may be brought about by means contrary to the covenants and obligations of the Pact of Paris of August 27, 1928, to which Treaty both China and Japan, as well as the United States, are parties. ${ }^{112}$

Although the United States was not a member state, the League of Nations Assembly, on March 11, 1932, unanimously adopted a British-proposed

109 Grant, supra note 3, at 92.

110 G.A. Res. 2775 (XXVI), § E (Nov. 29, 1971); G.A. Res. 3411 (XXX), § D (Nov. 28, 1975); G.A. Res. 31/6, § A (Oct. 26, 1976) (the homelands' independence was deemed "invalid").

111 O'Brien, supra note 12, at 185; Wright, supra note 12, at 548-49, 558; LAUTERPACHT, supra note 3, at 416-20; CRAWFORD, supra note 7, at 132-33.

112 United States Department of State, Peace and War: United States Foreign Policy 1931-1941 at 160 (1943) [hereinafter Peace and War]; United 
resolution, which stated: "it is incumbent upon the members of the League of Nations not to recognize any situation, treaty or agreement which may be brought about by means contrary to the Covenant of the League of $\mathrm{Na}$ tions or to the Pact of Paris."113

Thereby the concept of non-recognition had entered international law. There is, however, some doubt whether the League of Nations' Resolution is necessarily conclusive evidence of states' opinio juris at that time, as the Lytton Commission Report for the League of Nations, which was the basis for the Resolution, concluded that Manchukuo was not independent, but rather a Japanese puppet state. ${ }^{114}$

Notwithstanding the fact that the League of Nations' decision was almost certainly based on a complex set of motives, it must nevertheless be acknowledged that the unanimous decision by the Assembly, and the American support for the notion, do evidence widespread support for viewing the principle of non-recognition as legally valid. ${ }^{115}$

Accordingly, Article 11 of the Montevideo Convention of 1933 stated, " $t$ ] he contracting states definitely establish as the rule of their conduct the precise obligation not to recognise territorial acquisitions ... which have been obtained by force ...."116

The non-recognition of the incorporation of the Baltic States into the Soviet Union on the part of the Allies, as well as the non-recognition of border changes instigated by German, Italian, and Japanese aggression

States Department of State, Papers Relating to the Foreign Relations of the United States, Japan: 1931-1941 at 76 (1943).

113 See PeAce And War, supra note 112, at 4.

114 LAUTERPACHT, supra note 3, at 417; CrAWFORd, supra note 7, at 75-79.

115 Lador-Lederer, supra note 5, at 73; J.J. Lador-Lederer, Recognition-A Historical Stocktaking, 27 Nordic Journal of International Law 117, 128, 131 (1957) (Writing in 1957, Lador-Lederer disagrees. He argues that because many states were prepared to recognise "aggressions," the principle of non-recognition in the case of bellum injustum had not been established in law, but was only used as a political tool. He, however, overlooks the fact that states extending recognition always tried to justify the aggressions when recognising the results, claiming a case of bellum justum, thereby implying the existence of opinio juris in favour of assuming that a ban on recognition existed in cases of bellum injustum.).

Montevideo Convention, supra note 41. 
during the Second World War provides further evidence for the existence of the principle. ${ }^{117}$

After the Second World War, the prohibition on the use of force contained in Article 2(4) of the UN Charter reinforced the principle. Indeed, there have been numerous cases since then, when the Security Council has asked member states not to recognise territorial changes achieved by the illegal use of force. ${ }^{118}$ Well-known examples are the non-recognition of Northern Cyprus, ${ }^{119}$ and the annexation of Kuwait by Iraq. ${ }^{120}$ Some would argue that the widespread non-recognition of the incorporation of Crimea into the Russian Federation was another application of this rule of customary international law. ${ }^{121}$ The International Court of Justice has also repeatedly re-affirmed the legal validity of the principle of non-recognition. ${ }^{122}$

\section{c. Non-Recognition Based on the Unlawfulness of a Secession}

Among some, however, there seems to be an inclination to presume there is a third case of mandated non-recognition: a state created by secession.

117 GRANT, supra note 3, at 9; Lador-Lederer, supra note 115, at 126-28 (Although he views theses non-recognitions as more political than legal, and cites the case of Austria as an example. Having recognised the incorporation of Austria into Germany in 1938, the Allies declared that incorporation "null and void" in November 1943.).

118 Dugard, supra note 3, at 27-28.

119 S.C. Res. 541 (Nov. 18, 1983); S.C. Res. 550 (May 11, 1984); see also S.C. Res. 787 (Nov. 16, 1992) (it was made obvious that unilaterally declared entities seceding from Bosnia would not be recognised; this was in response to the declaration of the Republic of Srpska.).

120 S.C. Res. 662 (Aug. 9, 1990).

121 Theodore Christakis, Self-Determination, Territorial Integrity and Fait Accompli in the Case of Crimea, 75 ZeItschrift FÜR AusläNDISCHeS ÖFfENTLICHES RECHT UND VÖLKerReCht 75, at 96-99 (2015).

122 Legal Consequences for States of Continued Presence of South Africa in Namibia (South West Africa) Notwithstanding Security Council Resolution 276 (1970), Advisory Opinion, 1971 I.C.J. Rep. 16 (June 21); see also G.A. Res. 2625 (XXV), at 123 (Oct. 24, 1970) (requiring states not to recognise as legal any "territorial acquisition resulting from the threat or use of force," which is generally viewed as reflective of customary international law); ICJ Armed Activities on Congo, supra 
This is due to the belief that sessions are unlawful under international law, possibly bar rare exceptions. Many argue that there is, in the non-colonial context, no right for any group to secede from its mother country, except possibly in rare cases of "remedial secession". Only when a minority is denied its right to "internal" self-determination by suppressive means, can it possibly lay claim to a right of "external" self-determination, i.e. secession. There being no right to secession, some argue, the principle of territorial integrity renders any secession unlawful (on occasion, there is also a reference to the uti possidetis principle). ${ }^{123}$ ICJ Judge Koroma expressed this line of thought in Kosovo as follows:

A unilateral secession of a territory from an existing State without its consent, as in this case under consideration, is a matter of international law. The truth is that international law upholds the territorial integrity of a State. One of the fundamental principles of contemporary international law is that of respect for the sovereignty and territorial integrity of States. This principle entails an obligation to respect the definition, delineation and territorial integrity of an existing State. According to the principle, a State exercises sovereignty within and over its territorial domain .... Not even the principles of equal rights and self-determination of peoples as precepts of international law allow for the dismemberment of an existing State without its consent. ${ }^{124}$

These arguments have implications for state recognition. There seems to be an assumption that other states may not extend recognition to a seced-

note 16,162 (confirming the principle's customary international law status). See also, e.g., Charter of the Organization of American States art. 17, Apr. 30, 1948, 2 U.S.T. 2394, 119 U.N.T.S. 3.

123 Dugard, supra note 3, at 29, 121-32; Linda Hamid \& Jan Wouters, We the People: Self-Determination v. Sovereignty in the Case of De Facto States 4 (Leuven Ctr. For Glob. Governance Studies, Working Paper No. 166, 2015); Marxsen, supra note 21, at 26; Vidmar, supra note 10, at 708; Clifton van der Linden, Secession: Final Frontier for International Law or Site of Realpolitik Revival?, 5 JournaL of International Law ANd International Relations 1, 10 (2009) (claiming to discern a tendency in international law to judge a secession's legality based on international law).

124 ICJ Self-Government of Kosovo, supra note 2, gg 20-22 (Koroma, J., dissenting); DUGARD, supra note 3, at 86-87 (a view already expressed by UN Secretary General U Thant in 1970). 
ing entity, despite it meeting the statehood criteria, if the initial secession was unlawful, i.e. not justified at least as a remedial secession under international law. Others view all secessions in a non-colonial context as unlawful. ${ }^{125}$ In the Kosovo Case, Serbia described this position as follows:

... the norm of respect for the territorial integrity of States imports an additional requirement and this is to sustain the territorial wholeness or definition or delineation of particular States. It is a duty placed on all States and relevant non-state actors that the very territorial structure and configuration of a State must be respected . ... To put it another way, the obligation on all states is not simply to avoid trespassing across international borders, but to acknowledge and positively protect the territorial composition of other States. ${ }^{126}$

The Islamic Republic of Iran was even more emphatic: it claimed that the principle of territorial integrity was a jus cogens norm, prohibiting secession even in cases of severe human rights violations. ${ }^{127}$ These arguments are supposedly supported by state practice, the attempted secession by Katanga from the Democratic Republic of Congo, ${ }^{128}$ and the case of Somaliland being the examples cited most often. ${ }^{129}$

This line of reasoning is far from convincing. There is no evidence that it is unlawful to recognise a new state that is the result of an "unlawful" secession. The Canadian Supreme Court, after negating any right of Québec to secede from Canada under international law, nevertheless, concluded:

Although there is no right, under the Constitution or at international law, to unilateral secession, the possibility of an unconstitutional declaration of secession leading to a de facto secession is not ruled out. The ultimate success of such a secession would be dependent on recognition by the international community . . . .

125 Hamid \& Wouters, supra note 123, at 9-10.

126 Accordance with International Law of the Unilateral Declaration of Independence in Respect of Kosovo, Written Statement of Serbia, gg 423-424 (Apr. 15, 2009), http://www.icj-cij.org/docket/files/141/15642.pdf.

127 Accordance with International law of the Unilateral Declaration of Independence in Respect of Kosovo, Written Statement of the Islamic Republic of Iran, gg 2-4 (Apr. 17, 2009), http://www.icj-cij.org/docket/files/141/15646.pdf.

128 DugARD, supra note 3, at 159-61.

129 Dugard, supra note 3, at 138 (referring also to S.C. Res. 1766 (July 23, 2007) and S.C. Res. 1772 (Aug. 20, 2007) on Somalia); id. at 177-80. 
Even if granted, such recognition would not, however, provide any retroactive justification for the act of secession, either under the Constitution of Canada or at international law. ${ }^{130}$

Indeed, it would seem that a prohibition on recognizing seceding entities irrespective of whether they have achieved statehood would itself be unlawful, as it would amount to a clear violation of the principle of nonintervention in internal affairs.

\section{Secessions and Territorial Integrity in International Law}

International law is in fact silent as far as the lawfulness of secessions is concerned. ${ }^{131}$ As the Federal Republic of Germany explained in the Kosovo Case:

There is considerable authority for the proposition that a declaration of independence leading to a secession and secession itself are of an entirely factual nature and that international law in general is silent as to their legality... ${ }^{132}$

There are two exceptions: when a secession is the result of the unlawful use of force (such as the Japanese intervention in China that led to Manchukuo's secession) or is an attempt to suppress the majority population, as was the case when Rhodesia seceded from the United Kingdom in 1965. Otherwise, however, international law views secession as an internal matter for the state concerned. ${ }^{133}$ In 1920 already, the International Committee of Jurists on the Aaland Islands question stated:

On the contrary, in the absence of express provisions in international treaties, the right of disposing of national territory is essentially an attribute of the sovereignty of every State .... A dispute

130 Reference re Secession of Québec, [1998] 2 S.C.R. 217 (Can.).

131 Kirsten Schmalenbach, Casebook Internationales Recht 131 (2d ed. 2014); López-Jacoiste, supra note 94, at 222, 232; Dugard, supra note 3, at 88; Anne Peters, Does Kosovo Lie in the Lotus-Land of Freedom?, 24 Leiden Journal of International Law 94, 98-101; Hamid \& Wouters, supra note 123, at 6; Christakis, supra note 121, at 90-92.

132 Accordance with International Law of the Unilateral Declaration of Independence in Respect of Kosovo, Written Statement of Germany, 27 (Apr. 17, 2009), http:// www.icj-cij.org/docket/files/141/15624.pdf.

133 Schmalenbach, supra note 131, at 131. 
between two States concerning such a question, under normal conditions therefore, bears upon a question which International Law leaves entirely to the domestic jurisdiction of one of the States concerned. ${ }^{134}$

Once the secessionist movement, however, has been so successful that it can claim to fulfil all statehood criteria, international law does not prohibit recognition as a new state. Rather, this entity, that has become a new state according to customary international law, can now itself lay claim to the principle of territorial integrity. ${ }^{135}$ The ICJ, in its advisory opinion on Kosovo, confirms this. ${ }^{136}$ By stating that international law "contains no applicable prohibitions of declarations of independence", ${ }^{137}$ it emphasized that point. ${ }^{138}$

The Court has been severely criticized for its reasoning, with many arguing that the court had not only missed the chance to address the

134 Aaland Islands Question, supra note 36, at 8.

135 Christakis, supra note 121, at 92-93; Marxsen, supra note 21, at 16; WHEATLEY, supra note 12, at 2; Vidmar, supra note 10, at 709, 742 (while acknowledging this view to be widespread, he doubts its correctness).

136 ICJ Self-Government of Kosovo, supra note 2.

137 Id. 84; Schmalenbach, supra note 131, at 129.

138 ICJ Self-Government of Kosovo, supra note 2, gg 2, 4-6 (separate opinion of Yusuf, J.) (some criticize the court for having only dealt with the Kosovar declaration of independence without addressing secessions); DugARD, supra note 3, at 235-39; Stefan Oeter, The Kosovo Case - An Unfortunate Precedent, 75 Zeitschrift FÜR AUSLÄNDISCHES ÖFFENTLICHES ReCht Und VöLKERRECHT 51, 54-55 (2015) (he does not criticize the ICJ, however). Such criticism is, however, unjustified. The ICJ's Advisory Opinion can only be interpreted as having offered a verdict on the legality of unilateral secessions. This is evidenced by the reference to those cases when unilateral declarations of independence have been condemned by the international community (Southern Rhodesia, Northern Cyprus, Republic of Srpska). All the resolutions cited by the ICJ in this context were dealing with attempted secessions, i.e. separation from the mother country, not with inconsequential declarations of independence. This can be seen most clearly in the case of Southern Rhodesia - the independence of the British colony was an official UN goal. The declaration of independence, if judged when taken out of its context, could therefore only be lawful. Yet the actual secession in 1965 was an attempt to suppress the black majority, so that the independence declaration 
topic of state recognition, but that it had opened the door to chaos within the international community. ${ }^{139}$ Actually, the ICJ did no more than apply customary international law as it stands to the case before it. A secession by a minority is basically an internal matter for the state concerned, be it a secession by an ethnic minority living within a specific territory or by a part of a possibly federal state not necessarily characterized by minority status. ${ }^{140}$ This view usefully also obviates an analysis of what actually constitutes a "people" that can possibly lay claim to a right of self-determination, because the success of the secession is the only relevant criterion.

Any automatic prohibition on recognizing such a (successful) secession, on the other hand, would be a direct and unlawful intervention in the internal affairs of the other state by siding with the government of that state against an internal rebellion. Such conduct is prohibited under international law as a violation of the principle of non-intervention. The principle of non-intervention requires other states to refrain from supporting either side, because it is up to the people of the state concerned to decide on the way forward. Once that decision has resulted in the creation of a new state, it is not for other states to countermand that decision.

\section{THE PRINCIPLE OF NON-INTERVENTION IN ANOTHER STATE'S INTERNAL AFFAIRS}

The prohibition of any intervention in the internal affairs of another state is by now well established. According to Article 8 of the Montevideo

was seen to be unlawful. The fact the ICJ referred to this example of when such a declaration may be unlawful, strongly indicates the court was judging the legality of the Kosovar secession, not just the declaration of independence. See also ICJ Self-Government of Kosovo, supra note 2, 4 (separate opinion of Simma, J.) (his reasoning strongly indicates that he believed the court had provided an opinion on the accordance of secessions with international law); Peters, supra note 131, at $96,98$.

139 ICJ Self-Government of Kosovo, supra note 2, 6 (separate opinion of Yusuf, J.); DUGARD, supra note 3, at 244-45.

140 Schmalenbach, supra note 131, at 129, 131; Peter Hilpold, Selbstbestimmung und Autonomie - Zwischen Sezession und innerer Selbstbestimmung, in Аutonomie und Selbstbestimmung in Europa und im internationalen Vergleich 13, AT 15 (2016). 
Convention, concluded already in 1933, "no state has the right to intervene in the internal or external affairs of another." ${ }^{141}$ Following WW II this rule of customary international law has repeatedly been confirmed. Article 2(7) of the UN Charter rules out any the intervention by the UN in a member state's internal affairs. Regional treaties, also espoused this prohibition, for example Article 19 of the OAS Charter, concluded in $1948,{ }^{142}$ or Article 8 of the 1955 Warsaw Pact. ${ }^{143}$ Following these regional treaties a broad international consensus on the prohibition of intervention in another state's internal affairs developed. In 1965, the General Assembly passed the Declaration on the Inadmissibility of Intervention in the Domestic Affairs of States and the Protection of their Independence and Sovereignty by a 109:0:1 vote. ${ }^{144}$ These sentiments were reaffirmed in the 1970 General Assembly Declaration on Principles of International Law concerning Friendly Relations and Cooperation among States, which was passed without a vote: "No State or group of States has the right to intervene, directly or indirectly, for any reason whatever, in the internal or external affairs of any other State." 145

Although these resolutions were not legally binding as such, the fact they were passed by consensus, with the latter explicitly referring to international law, allows the conclusion that states viewed the content of the Declaration as being reflective of their interpretation of the international legal rules. It is therefore justified to view the prohibition on intervention in the internal or external affairs of another state as a rule of customary

141 Montevideo Convention, supra note 41.

142 Charter of the Organization of American States, Apr. 30, 1948, 119 U.N.T.S. 47.

143 Treaty of Friendship, Cooperation and Mutual Assistance, May 14, 1955, 219 U.N.T.S. 3.

144 G.A. Res. 2131 (XX) (Dec. 21, 1965) ("1. No State has the right to intervene, directly or indirectly, for any reason whatever, in the internal or external affairs of any other State. Consequently, armed intervention and all other forms of interference or attempted threats against the personality of the State or against its political, economic and cultural elements, are condemned.").

145 G.A. Res. 2625 (XXV) (Oct. 24, 1970). 
international law. In 2005, the ICJ confirmed that the Friendly Relations Resolution was "declaratory of international law". 146

The ICJ itself has repeatedly stressed the legal quality of the prohibition of such interventions. As early as 1949, only shortly after the ICJ came into being, the Court expressly deemed interventions in other states' affairs as unlawful. ${ }^{147}$ In the Nicaragua Case, in 1986, the ICJ went into more detail by providing at least a partial definition of the prohibition on interventions:

The principle of non-intervention involves the right of every sovereign State to conduct its affairs without outside interference; though examples of trespass against this principle are not infrequent, the Court considers that it is part and parcel of customary international law .... ${ }^{148}$ A prohibited intervention must accordingly be one bearing on matters in which each State is permitted, by the principle of State sovereignty to decide freely. One of these is the choice of a political, economic, social and cultural system, and the formulation of foreign policy. Intervention is wrongful when it uses methods of coercion in regard to such choices, which must remain free ones. ${ }^{149}$

Non-intervention entails not only refraining from external support of secessionist movements in other states, but also demands foregoing external support of that state's government once conflict has erupted. ${ }^{150}$ This principle of non-intervention in combination with the right of self-determination has led many, the author included, ${ }^{151}$ to conclude that customary international law prohibits any intervention, even in cases of civil war - civil war sometimes being the worst kind of precursor to a successful secession. ${ }^{152}$ Against this backdrop, it seems entirely consistent that the ICJ should conclude in Kosovo that the principle of territorial integrity is applicable

146 ICJ Armed Activities on Congo, supra note 16, 162.

147 Corfu Channel (U.K. v. Alb.), Judgment, 1949 I.C.J. Rep. 4, 34-35 (Apr. 9).

148 Nicar. v. U.S., 1986 I.C.J. Rep. 202; see also ICJ Armed Activities on Congo, supra note 16, gg 161-165.

149 Nicar. v. U.S., 1986 I.C.J. Rep. 205.

150 Oeter, supra note 138, at 69-70.

151 Patrick C. R. Terry, Afghanistan's Civil War (1979-1989): Illegal and Failed Foreign Interventions, 31 Polish Yearbook of International Law 107 (2011).

152 See, e.g., infra notes 164-65 (as far as South Sudan and Eritrea are concerned); Oeter, supra note 138, at 69-70. 
only to relations between states and not to relations between a state and a secessionist non-state actor acting within its territory. ${ }^{153}$ Declaring the principle of territorial integrity as applicable to internal non-state actors would have otherwise sanctioned outside intervention by legalizing support for the government in an internal conflict.

\section{UTI POSSIDETIS}

As for the principle of uti possidetis, it is doubtful whether this "general principle of international law" is truly applicable outside of the colonial context. ${ }^{154}$ The ICJ so far seems to have limited the principle's application to the decolonization process:

The essence of the principle lies in its primary aim of securing respect for the territorial boundaries at the moment when independence is achieved ... Uti possidetis . . is therefore a principle of a general kind which is logically connected with this form of decolonization wherever it occurs. ${ }^{155}$

The attempt of the EC to declare it to be a general principle of international law, applicable outside of the decolonization process, in order to safeguard Yugoslavia's internal, administrative boundaries, has not managed to set a precedent, ${ }^{156}$ as many of those and other states chose to ignore the precedent when recognizing Kosovo. ${ }^{157}$ The EU itself has ignored the principle even within the decolonisation process when it admitted the island of Mayotte, as a part of France, to that organization, although it had seceded from the

153 ICJ Self-Government of Kosovo, supra note 2, g9 79-80; DugARD, supra note 3, at 137; WheAtley, supra note 12, at 2. But see Marxsen, supra note 21, at 7-26 (especially at 13-14); Vidmar, supra note 10, at 708, 710-19 (claiming there is a necessity in international law of a waiver by the parent state in regard of its territorial integrity for other states to be permitted to recognise the seceding entity as a state).

154 Dugard, supra note 3, at 226.

155 Frontier Dispute (Burk. v. Mali), Judgment, 1986 I.C.J. Rep. 554, 23 (Dec. 22).

156 DugARD, supra note 3, at 129-30, 226-27.

157 Id. at 274. 
Union of Comoros on independence in $1975 .{ }^{158}$ It should also be noted that the Roman legal principle, from which uti possidetis derives, only stipulates that property that is disputed should be viewed as belonging to the current possessor. ${ }^{159}$ A successful secession, resulting in a new state, can then of course itself lay claim to this principle. ${ }^{160}$ As Dugard has explained, the principle is in any case only relevant, if at all in a non-colonial context, to the creation of a new state, rather than it being of a "continuing nature that comes into effect after a territory has established itself as a State", which is an issue of territorial integrity. ${ }^{161}$

Any other conclusion would lead to the absurd result that other states would have been granted the explicit right to intervene in another state's affairs: demanding collective non-recognition of a new state created by a successful secession would, in effect, result in unequivocal support for the government side in an internal conflict.

\section{STATE PRACTICE}

State practice does not evidence that states view secessions in a noncolonial context as illegal. The often cited non-recognition of Katanga was

158 Geographically, the island is a part of the Union of Comoros which became independent from France in 1975. In the referendum on independence in 1974 the Island of Mayotte was the only territory within the Comoros to vote against independence. Since then the island has continued to be ruled by France, a situation the Union of Comoros refuses to recognise. Despite a large majority of the island's inhabitants supporting French rule (in a 2009 referendum $95 \%$ of the population voted in favour of Mayotte becoming a French "départment"), the General Assembly has repeatedly reaffirmed the sovereignty of the Union of Comoros over the island. See, e.g., G.A. Res. 37/65 (Dec. 3, 1982); G.A. Res. 49/18 (Nov. 28, 1994). In 1976, a draft resolution of the Security Council, recognising the sovereignty of the Union of Comoros, received 11 affirmative votes, but was vetoed by France. On 1 January 2014, the island, nevertheless, became a part of the European Union.

159 Dugard, supra note 3, at 131.

160 Martin Ott, Das Recht auf Sezession als Ausfluss des SelbstbestimmungsRechts der VölKer 466 (2008).

161 Dugard, supra note 3, at 130; OTT, supra note 160, 363-65. 
accompanied by references to the illegality of the attempted secession; ${ }^{162}$ however, the support provided by Belgium, the former colonial power, to the secessionists, seems to have been the main motivating factor behind these condemnations. ${ }^{163}$ Even during the decolonization period, when states emphasized the importance of retaining current borders, attempts at secession, while certainly not supported, were always referred to as an "internal matter" of the state concerned. ${ }^{164}$ Besides Katanga, other examples are sometimes cited when "successful" secessions were denied recognition. A common factor of all these examples, however, is that most authors claim that the statehood criteria were met by the seceding entity for at most two years. That in itself makes it doubtful effective statehood had been truly achieved and is much more likely a sign of a situation in flux when the principle of non-intervention demands refraining from recognition. ${ }^{165}$

On the other hand, there have been successful secessions, which were recognised by the international community in disregard of the principle of territorial integrity or uti possidetis: Bangladesh, Eritrea and South Sudan. ${ }^{166}$ If the break-up of Yugoslavia is seen as a process of multiple secessions instead of dissolution, then Croatia, Slovenia, Bosnia-Herzegovina and Macedonia must be added to that list. ${ }^{167}$ Some scholars dismiss these examples by going to great lengths to justify Bangladesh's secession as

162 S.C. Res. 169 (Nov. 24, 1961).

163 Id.; Отт, supra note 161, at 223, 225; Lawrence S. Eastwood Jr., Secession: State Practice and International Law after the Dissolution of the Soviet Union and Yugoslavia, 3 Duke Journal of Comparative and International LaW 299, 305-07 (1993) (pointing out that Baluba wanted to secede from Katanga, raising doubts as to whether the majority of Katanga's population actually supported independence).

164 Regarding Katanga, see S.C. Res. 161 (Feb. 21, 1961); regarding Biafra, see Отт, supra note 160 , at 232 .

165 Regarding Katanga, see Отт, supra note 160, at 226; regarding Biafra, see id. at 229-35 (Biafra was recognised by a few states); regarding Bougainville, see id. at 252-53; Dugard, supra note 3, at 172-73.

166 Hilpold, supra note 140, at 15; DUGARD, supra note 3, at 87; Eastwood, supra note 163 , at $310-13$.

167 Dugard, supra note 3, at 88, 191-96; Oтт, supra note 160, at 313-27; Eastwood, supra note 163, at 300; Richard F. Iglar, The Constitutional Crisis in Yugoslavia and the International Law of Self-Determination: Slovenia's and Croatia's Right 
remedial, while emphasizing the consensual nature of the secession in the other two cases, and treating Yugoslavia as a case of dissolution. However, the fact is that all these secessions were successful and most were the result of the use of force. In Bangladesh's case, secession was achieved with the military help of India; ${ }^{168}$ Eritrea ${ }^{169}$ and South Sudan ${ }^{170}$ were both created as a result of a decades-long civil war. The fact the international community was in the end able to convince the parent states, Ethiopia and Sudan, to accept the inevitable does not make these separations "consensual". ${ }^{171}$

There is, however, one seemingly clear case: the case of Somaliland, where a successful secession, i.e. the creation of a new state on the territory of another state, has been met by collective non-recognition without such conduct being mandated by any international organisation. Somaliland declared its independence from Somalia in 1991. There is near consensus that since its independence, Somaliland has always met and still meets the criteria of statehood, while Somalia itself, for many years, has been judged as a "failed state." Nevertheless, Somaliland has not been recognized by other states. ${ }^{172}$ It seems that this is mainly due to political not legal considerations. ${ }^{173}$ For instance, many fear that recognising Somaliland will unleash other states across Africa that wish to be recognised. ${ }^{174}$ There are also concerns that recognition of Somaliland might spark further secessions from Somalia, leading to further conflict in the war-ravaged

to Secede, 15 Boston College International and Comparative Law Review 213, 213-19 (1992).

168 OTT, supra note 160, at 236-44; DugARD, supra note 3, at 187-91; Eastwood, supra note 163 , at $311-12$.

169 OTT, supra note 160, at 254-61; DUgARD, supra note 3, at 179-80, 196-98.

170 Отт, supra note 160, at 353-55; DugARD, supra note 3, at 173, 198-201.

171 Nikola Pijovic, To Be or Not to Be: Rethinking the Possible Repercussions of Somaliland's International Statehood Recognition, 14 African Studies QuARTERly 17, 21-22 (2014). But see Vidmar, supra note 10, at 714 (regarding Ethiopia's and Sudan's agreement to Eritrea's and South Sudan's secession as decisive).

172 See also Eggers, supra note 51, at 211-22; Pijovic, supra note 171, at 17-36.

173 Pijovic, supra note 171, at 18.

$174 \quad I d$. at 21. 
country. ${ }^{175}$ Many also believe that Somaliland's independence should be part of a comprehensive peace agreement, covering the whole Somalia. ${ }^{176}$ On the other hand, there does seem to be a basic willingness to recognise Somaliland, as evidenced by Somaliland's "engage[ment] with the United Nations, the Arab League, the EU, and nations such as Britain, America, and Denmark." ${ }^{177}$ In fact, no state has claimed that recognizing Somaliland would be illegal under international law.

That there is no rule demanding non-recognition of states created by secession is also evidenced by Article 41 of the International Law Commission's Articles on State Responsibility, generally viewed as reflective of customary international law, which demands non-recognition only of situations created by a violation of jus cogens norms. Contrary to Iran's view, the principle of territorial integrity is not such a jus cogens norm as evidenced by the successful secessions just outlined. ${ }^{178}$

Having thus found no rule in customary international law that prohibits the recognition of states that have seceded (bar the two exceptions explained), the rarity of successful secessions must, nevertheless, be acknowledged. However, this is not due to customary international law, but rather to the enormous difficulties associated with establishing a new state on the territory of a parent state that is understandably resisting any such move. ${ }^{179}$ Often secession will only be achieved by the use of force, with all the subsequent calamities, including foreign involvement. This will, of course, deter many would-be-secessionists. Furthermore, other states are hesitant to support secessionist movements by extending recognition, as most states are themselves faced with restive provinces demanding more autonomy or independence. Not only Russia and China, but also France and Spain are reluctant to offer any encouragement to secessionist movements lest they themselves soon be exposed to the same demands. It is therefore in the interest of most states that secessions fail. ${ }^{180}$ No state

\footnotetext{
175 Id. at 24.

176 T.G., supra note 25.

177 Id.

178 López-Jacoiste, supra note 94, at 232-33.

179 Id. at 232.

180 Hilpold, supra note 140, at 46; Hofmeister \& Giupponi, supra note 27, at 205; Eastwood, supra note 163, at 307-09, 314-16; Oeter, supra note 138, at 63.
} 
is interested in increasing worldwide instability by admitting dozens of new states to the international community. ${ }^{181}$ Probably more importantly, no state wants to provide another state with an excuse for recognizing its own secessionist movement by previously generously recognizing other states' dismemberment. ${ }^{182}$

These reactions, however, are not based on any legal principles to be found in customary international law, but are rather the result of selfinterest and other motives rooted in the political sphere. Valid political considerations must be seen, nevertheless, as completely separate from the legal assessment. The fact that a new state has been created by successful secession grants other states the right to recognise it as such. ${ }^{183}$ Whether they do so, is, as explained previously, at their own discretion. ${ }^{184}$

Having examined when international law demands that a state is not recognised as such, it remains to be examined what the consequences of the opposite scenario are: the recognition of an entity as a state despite it not fulfilling those criteria. This is where customary international law on recognition of states and secessions truly overlap.

\section{PREMATURE RECOGNITION AND SECESSIONS}

\section{a. Premature Recognition}

Although the decision whether to recognise another state is still widely seen as being the prerogative of the individual recognizing state, there is agreement that recognizing an entity as a state before it fulfils the criteria of statehood is unlawful. ${ }^{185}$ The issue of premature recognition becomes especially pertinent in cases of secession. A state that recognises a seceding entity as a state before it fulfils the criteria of statehood is guilty of inter-

181 Eastwood, supra note 163, at 314-16; Oeter, supra note 138, at 69.

182 Hofmeister \& Giupponi, supra note 27, at 205.

183 Dugard, supra note 3, at 134-35; Eastwood, supra note 163, at 313.

184 López-Jacoiste, supra note 94, at 241.

185 Briggs, supra note 14, at 171; Ruda, supra note 12, at 451; O'BRIEN, supra note 12, at 186-87; BAER, supra note 12, at 318-23; Grant, supra note 12, at 326; Wright, supra note 12 , at 556 . 
ference in the domestic affairs of the parent state, ${ }^{186}$ and therefore violates the principle of non-interference by supporting the secessionists against the other state's government. Premature recognition violates the principle of territorial integrity, which applies to the relations between states as the ICJ has again emphasized. ${ }^{187}$

Long before the UN Charter came into force there was near universal agreement that premature recognition was contrary to international law. ${ }^{188}$ Already in 1874, Theodore Woolsey declared that:

If the question is still one of armed strife, as between a colony and the mother country, or between a state and a revolted portion of it, to take the part of the colony or of the revolted territory by recognition is an injury and may be a ground of war . . . ${ }^{189}$

William Hall, writing in 1924, also maintained that, "Until independence is so consummated that it may reasonably be expected to be permanent, insurgents remain legally subject to the state from which they are trying to separate. Premature recognition is therefore a wrong done to the parent state; in fact it amounts to an act of intervention." 190

Hall goes on to describe American and British reluctance to recognise the South American "Spanish" Republics' independence from Spain between 1810 and 1825 as due to their common wish to avoid a violation of international law. ${ }^{191}$ A report before the Senate Foreign Affairs Commit-

186 Ruda, supra note 12, at 451; O'BRIEN, supra note 12, at 186-87; BAER, supra note 12, at 318-23; Grant, supra note 12, at 326; Wright, supra note 12, at 556-57 ("states can, therefore, promote their policies by recognizing facts not yet established . . .."); LAWRENCE, supra note 49, at 85-86; Dugard, supra note 3, at 23-26; Oeter, supra note 138, at 70-71. But see Vidmar, supra note 10, at 743-47 (viewing the concept of premature recognition as outdated).

187 ICJ Self-Government of Kosovo, supra note 2, 80.

188 LAUTERPACHT, supra note 3, at 9-12; LAWRENCE, supra note 49, at 85-86 (writing in 1923, describing premature recognition as "an act of intervention which the parent state had a right to resent, as she did, by war," thereby referring to the French recognition of American independence in 1778).

189 Woolsey, supra note 43, at 41.

190 HALL, supra note 13, at 105, supported in Hershey, supra note 13, at 208; LAWRENCE, supra note 49 , at 85-86.

191 HALL, supra note 13, at 105-08. 
tee on the question of their recognition stated: "[t]he political right of the United States to acknowledge the independence of the Spanish American Republics, without offending others, does not depend upon the justice but on the actual establishment of that independence."192

Similarly, Hersch Lauterpacht stated in 1947 "It is generally agreed that premature recognition is more than an unfriendly act; it is an act of intervention and an international delinquency." 193

He cites-among others - the examples of French recognition of the United States in 1778, and the US recognition of Panama in 1903 as having been contrary to international law. ${ }^{194}$ According to Dugard, the US later even payed Colombia reparations for prematurely recognizing Panama. ${ }^{195}$ Hershey, writing in 1927, besides also citing these two examples, views the recognitions of Belgium and Greece in 1827-1830 "by the Powers", and the recognition of Cuba in 1898 as "premature", an "intervention in the guise of recognition", and therefore as a "gross affront to the parent State."196

The declaratory theory of recognition supported here means that the act of recognition does not alter the facts: the entity recognised as a state does not thereby become one. Nevertheless, it is self-evident that in cases of secession premature recognition amounts to actively supporting one side in an internal conflict, thereby ignoring the parent state's still existing sovereignty. ${ }^{197}$

Such premature recognition, of course, can be an attempt by the recognizing state to legitimize subsequent intervention at the putative new state's request.

As Lauterpacht points out, such action is, however, illegal in another respect: it ignores the criteria developed in customary international law

$192 I d$. at 106.

193 LAUTERPACHT, supra note 3, at 8.

194 Id.; see, e.g., BAER, supra note 12, at 321; LAWRENCE, supra note 49, at 86 (citing French recognition of U.S. independence as an example).

195 Dugard, supra note 3, at 26, 38.

196 Hershey, supra note 13, at 208.

197 BAER, supra note 12, at 322; LAWRENCE, supra note 49, at 85-86; SCHMALENBACH, supra note 131, at 145; Oeter, supra note 138, at 56; Memorandum by the Legal Adviser (Gross) to the Under Secretary of State (Lovett), Recognition of Successor States in Palestine, 5 Foreign Relations of the United States 960, 960 (1948). 
as regards statehood, and thereby unlawfully complicates the conduct of international relations within the international community to the disadvantage of all other states. The recognizing state is forced to treat the non-state as a state in bilateral relations, while the rest of the international community rightfully does not treat it as such. Such conduct therefore amounts to an "abuse of the power of recognition". ${ }^{198}$ Besides being an intervention, premature recognition is therefore also a recipe for chaos within the international community.

Therefore a seceding entity can only be recognised as a state once it has met all statehood criteria. As long as that is not the case and the parent state could possibly still reassert its control over the rebellious part of its territory, other states are prevented from extending recognition. Premature recognition is an intervention in the internal affairs of another state and therefore unlawful. ${ }^{199}$ This legal situation also contradicts what many critics of the ICJ's advisory opinion on Kosovo assert: far from ushering in an era of chaos and instability, the strict application of the rules on recognition set a very high bar to achieving independence. Achieving statehood on another state's territory against that state's wishes is no mean achievement and, when attained, certainly evidences that the mother country has, in any case, already lost effective control.

\section{b. "Remedial" Secession and Recognition}

\section{THE RIGHT OF REMEDIAL SECESSION}

This relatively clear legal situation, which, as is often the case in customary international law, sometimes is obscured by varying state practice, however, may be in danger. ${ }^{200}$ As explained, international law does generally not take a view on the legality of secessions. Nevertheless, many argue that there is at the very least a "presumption" against secession in international law. ${ }^{201}$ Some of those, however, allow an exception in the case of so-called

\footnotetext{
198 LAUTERPACHT, supra note 3, at 8.

199 Schmalenbach, supra note 131, at 145.

200 Eastwood, supra note 163, at 300.

201 Peters, supra note 131, at 98-102 (outlining this argument).
} 
"remedial" secessions. ${ }^{202}$ This claimed right to secession in extraordinary circumstances is also supported by some who agree that international law basically does not regulate secession. ${ }^{203}$

As early as 1920, the International Committee of Jurists on the Aaland Islands question thought it possible that such a right may exist. After ruling out a general right to secede under international law, the committee continued:

The Commission, in affirming these principles, does not give an opinion concerning the question as to whether a manifest and continued abuse of sovereign power, to the detriment of a section of the population of a State, would, if such circumstances arose, give to an international dispute, arising therefrom, such a character that its object should be considered as one which is not confined to the domestic jurisdiction of the State concerned, but comes within the sphere of action of the League of Nations. ${ }^{204}$

It seems that, almost a century later, the right of remedial secession has not made much progress. ${ }^{205}$ In its 2010 advisory opinion on Kosovo, the ICJ referred to the right of remedial secession as follows:

Whether, outside the context of non-self-governing territories and peoples subject to alien subjugation, domination and exploitation, the international law of self-determination confers upon part of the population of an existing State a right to separate from that State is, however, a subject on which radically different views were expressed by those taking part in the proceedings and expressing a position on the question. Similar differences existed regarding whether international law provides for a right of "remedial secession" and, if so, in what circumstances. There was also a sharp difference of views as to whether the circumstances which some participants maintained would give rise to a right of "remedial secession" were

202 DugARD, supra note 3, at 211, 217-19, 222-25; Hamid \& Wouters, supra note 123, at 5-6; Anatoly Kapustin, Crimea's Self-determination in the Light of Contemporary International Law, 75 ZEITSCHRIFT FÜR AUSLÄNDISCHES ÖFFENTLICHES RECHT Und VölKerrecht 101 (2015) (viewing Crimea as a case of remedial secession from the Ukraine).

203 López-Jacoiste, supra note 94, at 222, 232; Отт, supra note 160, at 360-65.

204 Aaland Islands Question, supra note 36, at 8.

205 Christakis, supra note 121, at 88-89; van der Linden, supra note 123, at 3. 
actually present in Kosovo. The Court considers that it is not necessary to resolve these questions in the present case. ${ }^{206}$

Nevertheless, some have claimed that such a right exists. ${ }^{207}$ As early as 1921, the Commission of Rapporteurs, again considering the Aaland Islands questions, seemed to affirm such a right of remedial secession. ${ }^{208}$ The starting point for the current discussion is, however, the Friendly Relations Declaration:

Nothing in the foregoing paragraphs shall be construed as authorizing or encouraging any action which would dismember or impair, totally or in part, the territorial integrity or political unity of sovereign and independent States conducting themselves in compliance with the principle of equal rights and self-determination of peoples as described above and thus possessed of a government representing the whole people belonging to the territory without distinction as to race, creed or colour. ${ }^{209}$

While repeating states' obligation to respect other states' territorial integrity, this obligation seems to be limited to states "conducting themselves in compliance with the principle of equal rights and self-determination of peoples". A state that disregards the self-determination of its peoples and discriminates against a section of its population can therefore, it is argued, not invoke the principle of territorial integrity in order to stop other states

206 ICJ Self-Government of Kosovo, supra note 2, g9 82-83.

207 López-Jacoiste, supra note 94, at 222; Отт, supra note 160, at 313-27, 460-64; DugARD, supra note 3, at 211, 217-19.

208 Written Statement of Finland, 7 (Apr. 16, 2009), http://www.icj-cij.org/docket/ files/141/15630.pdf. Report Presented by the Commission of Rapporteurs, League of Nations Doc. B.7.21/68/106 at 28 (1921) ("The separation of a minority from a State of which it forms a part and its incorporation in another State can only be considered as an altogether exceptional solution, a last resort, when the State lacks either the will or the power to enact and apply just and effective guarantees.") (as quoted in the Written Statement of Finland).

209 G.A. Res. 2625 (XXV) (Oct. 24, 1970). 
recognizing the secession of an oppressed people. ${ }^{210}$ The Russian Federation thus stated in the Kosovo Case:

In this regard, the Russian Federation is of the view that the primary purpose of the "safeguard clause" is to serve as a guarantee of territorial integrity of States. It is also true that the clause may be construed as authorizing secession under certain conditions. However, those conditions should be limited to truly extreme circumstances...$^{211}$

Accepting a right of remedial secession necessitates a definition of what actually constitutes a people. This is controversial, ${ }^{212}$ but it is usually assumed that a people must have common features that distinguish it from other inhabitants of the mother country (objective criteria, such as religion, culture, ethnicity) and this group of citizens should view themselves as a distinct people (subjective criterion). ${ }^{213}$ The African Commission of $\mathrm{Hu}-$ man and Peoples' Rights, in the Katanga Case, did certainly not rule out the possibility of such a remedial right:

In the absence of concrete evidence of violations of human rights to the point that the territorial integrity of Zaire should be called to question and in the absence of evidence that the people of Katanga are denied the right to participate in government as guaranteed by Article 13(1) of the African Charter, the Commission holds the view that Katanga is obliged to exercise a variant of self-determination

210 Schmalenbach, supra note 131, at 131.

211 Accordance with International Law of the Unilateral Declaration of Independence in Respect of Kosovo, Written Statement of the Russian Federation, 88 (Apr. 16, 2009), http://www.icj-cij.org/docket/files/141/15628.pdf.

212 Katangese Peoples' Congress v. Zaire, (2000) AHRLR 72 (ACHPR 1995) (the African Commission on Human and Peoples' Rights stated that "[a]ll peoples have a right to self-determination. There may, however, be controversy as to the definition of peoples and the content of the right."); Hofmeister \& Giupponi, supra note 27, at 203; López-Jacoiste, supra note 94, at 228-30; DugARD, supra note 3, at 107-21; Oeter, supra note 138, at 57-58.

213 Schmalenbach, supra note 131, at 131. 
that is compatible with the sovereignty and territorial integrity of Zaire. ${ }^{214}$

Ground-breaking, however, and therefore frequently cited in this context, is the decision by the Canadian Supreme Court on a possible secession by Québec from Canada:

The Court was also required to consider whether a right to unilateral secession exists under international law. Some supporting an affirmative answer did so on the basis of the recognized right to self-determination that belongs to all "peoples." Although much of the Quebec population certainly shares many of the characteristics of a people, it is not necessary to decide the "people" issue because, whatever may be the correct determination of this issue in the context of Quebec, a right to secession only arises under the principle of self-determination of people at international law where "a people" is governed as part of a colonial empire; where "a people" is subject to alien subjugation, domination or exploitation; and possibly where "a people" is denied any meaningful exercise of its right to self-determination within the state of which it forms a part. In other circumstances, peoples are expected to achieve self-determination within the framework of their existing state. ${ }^{215}$

Based on these hints at a right of remedial secession, a distinction is made between "internal" and "external" self-determination. A people is basically only entitled to "internal" self-determination, i.e. within an existing state. Only when it is not/no longer possible to realize this right in any meaningful way, does international law, it is argued, confer upon such a people the right of "external" self-determination, i.e. the right to secede. ${ }^{216}$

In line with the more recent doctrines of humanitarian intervention or the Responsibility to Protect, the recognition of states thus might be in the process of becoming a new tool in order to enforce "humanitarian" goals. Some states certainly seem to be moving from viewing secession as not governed by international law towards accepting a right of "remedial"

\footnotetext{
214 Katangese Peoples' Congress v. Zaire, (2000) AHRLR 72.

215 Reference re Secession of Quebec, [1998] 2 S.C.R. (emphasis added).

216 López-Jacoiste, supra note 94, at 224; Отт, supra note 160, at 460-64; Hamid \& Wouters, supra note 123, at 3; Oeter, supra note 138, at 61-62.
} 
secession. In the proceedings before the ICJ in the Kosovo Case, Finland was unequivocal that such a right of remedial secession existed:

The acts of the FRY authorities in the relevant period demonstrated that 'the State either lacks the will or the power to enact and apply just and effective guarantees'. Kosovo could not expect to enjoy meaningful internal self-determination as part of the FRY. In view of the continuing suppression by the authorities of the FRY of the right of self-determination, and in the absence of any guarantees that such suppression would cease, the only realistic solution was to realize the right by independent statehood. ${ }^{217}$

As pointed out the Russian Federation, ${ }^{218}$ but also Romania, Germany, the Netherlands, Switzerland, Ireland, Poland, and others claimed there was a right of remedial secession in international law, while the USA, China, and France avoided expressing an opinion. ${ }^{219}$ Judge Yusuf indicated some support for this position in his Separate Opinion in the Kosovo Case. Referring to the passage of the Friendly Relations Declaration quoted above, he stated:

This provision makes it clear that so long as a sovereign and independent State complies with the principle of equal rights and self-determination of peoples, its territorial integrity and national unity should neither be impaired nor infringed upon. It therefore primarily protects, and gives priority to, the territorial preservation of States and seeks to avoid their fragmentation or disintegration due to separatist forces. However, the saving clause in its latter part implies that if a State fails to comport itself in accordance with the principle of equal rights and self-determination of peoples, an exceptional situation may arise whereby the ethnically or racially distinct group denied internal self-determination may claim a right of external self-determination or separation from the State which

217 Accordance with International Law of the Unilateral Declaration of Independence in Respect of Kosovo, Written Statement of Finland, 7 (Apr. 16, 2009), http://www. icj-cij.org/docket/files/141/15630.pdf.

218 Accordance with International Law of the Unilateral Declaration of Independence in Respect of Kosovo, Written Statement of the Russian Federation, g 88 (Apr. 16, 2009), http://www.icj-cij.org/docket/files/141/15628.pdf. 
could effectively put into question the State's territorial unity and sovereignty. ${ }^{220}$

As demonstrated, there is some support for the right of remedial secession among academics and states, It is now necessary to discuss what effects such a right might have on the law of state recognition.

\section{EFFECTS ON THE LAW OF STATE RECOGNITION}

Although it is at this stage still very doubtful that a right of remedial secession has really developed in customary international law $^{221}$ and correspondent opinio juris is currently still lacking, customary international law on state recognition may, nevertheless, be slowly evolving in order to accommodate remedial secessions. ${ }^{222}$ The consequence seems to be the creation of an exception to the prohibition on premature recognition. In recent times, states, such as the Kosovo, have been recognised by many other states although they undoubtedly do not fulfil the statehood criteria. Possibly, therefore, some states are beginning to view a remedial right of secession based on humanitarian grounds as a justification for prematurely recognizing other states. ${ }^{223}$ Tomuschat seems to advocate such an approach which he sees as evidence of "the new thinking in the field of international law":

Thus, it appears that the issue of premature recognition cannot completely be separated from the other question of whether "remedial secession exists" as a legal concept. Where an ethnic group may claim a right to secession on account of the massive discrimination which it has suffered thirds states can hardly be

220 ICJ Self-Government of Kosovo, supra note 2, 12 (separate opinion of Yusuf, J.); see also id. $g$ 182-184 (separate opinion of Cancado Trindade, J.).

221 Hilpold, supra note 140, at 39-41; López-Jacoiste, supra note 94, at 234.

222 ICJ Self-Government of Kosovo, supra note 2, 99 82-83 (the ICJ did not decide whether there is such a "remedial right" of secession based on the right of selfdetermination, but pointed out that this was a "subject on which radically different views were expressed by those taking part in the proceedings"); López-Jacoiste, supra note 94, at 242 (who, while doubting a right of remedial secession exists, nevertheless acknowledges that states "may be more likely to grant recognition" in such cases).

223 Vidmar, supra note 10, at 737, 739-40. 
denied the right to recognize this legal position and to draw the requisite conclusions. ${ }^{224}$

Ott sees some evidence for this in state practice:

In the cases of Bangladesh, Croatia and Bosnia and Herzegovina, of the former constituent republics of the USSR and of Eritrea, recognition was only confirmation of statehood; a statehood that partly did not satisfy the effectiveness criterion, but that was nevertheless legitimatized by the principle of self-determination and therefore legally existent. ${ }^{225}$

This position is confirmed by Wilde:

The significance of the external self-determination entitlement is that, if it is present, it can tip the balance in favour of statehood even when the entity does not meet the ordinary viability test. Examples here would be former colonial states in the period immediately following decolonization, and Bosnia and Herzegovina in the first half of the 1990s. ${ }^{226}$

Again, Finland, in its statement to the ICJ in the Kosovo Case, proposed exactly that:

A critical aspect of the situation at hand is the international presence established by UN Security Council resolution 1244 (1999) . ... The involvement of the international community is part of the way Kosovo resembles other situations involving UN assistance, such as East Timor, where limitation of internal self-determination, accompanied by serious human rights violations have opened the door to secession and independent statehood. In these cases, the assessment of effective control is complicated by the extensive international presence.... The creation of states out of long and violent struggles rarely fulfils criteria discussed in ideal theories of democratic representation .... Bearing in mind what has been said

224 Christian Tomuschat, Recognition of New States - The Case of Premature Recognition, in Kosovo and International Law, The ICJ Advisory Opinion OF 22 JUly 2010, at 31, 42-43 (Peter Hilpold ed., 2012).

225 Отт, supra note 160, at 465 (translation by author).

226 Ralph Wilde, Kosovo: International Law and Recognition, in A Summary of the Chatham House International Law Discussion Group Meeting Held ON 22 April 2008, at 8, 19 (2008), https://www.chathamhouse.org/sites/files/ chathamhouse/public/Research/International\%20Law/il220408.pdf. 
above about the abnormal nature of the situation, and the rationale of the self-determination principle, there seems little doubt that, if international law were to ignore or by-pass the Declaration of Independence, it would not serve one of the principal functions it has to provide for stable and lasting solutions for territorial disputes that are based on respect for fundamental rights and freedoms. ${ }^{227}$

The UK, which itself recognised Kosovo on 18 February 2008, hinted at that possibility as well, when it concluded in the Kosovo Case in 2009 that:

developments that have occurred since 17 February 2008 have crystallized Kosovo's independence, resolving any doubts and curing any deficiency that may have existed. Of particular significance in this regard are ... (2) the fact that the Kosovo authorities peacefully control and administer most of the territory and command the allegiance of the vast majority of the people of Kosovo . . . 228

The question is whether state practice confirms these arguments. As Wilde pointed out, there have always been some tendencies to be less strict in judging whether an entity meets the statehood criteria in cases when the secession was a clear-cut expression of the right of self-determination, i.e. during the process of decolonization. Some former colonies lacked an effective government on independence as their societies were embroiled in civil conflict. Nevertheless, the overwhelming majority of states immediately recognised these former colonies as new states once they had achieved independence. $^{229}$

However, it is very difficult to draw any conclusions from these events as they were characterized by the former colonial power having relinquished

227 Accordance with International Law of the Unilateral Declaration of Independence in Respect of Kosovo, Written Statement of Finland, gg 8-10 (Apr. 16, 2009), http:// www.icj-cij.org/docket/files/141/15630.pdf.

228 Accordance with International Law of the Unilateral Declaration of Independence in Respect of Kosovo, Written Statement of the United Kingdom, 99 127-128 (Apr. 17, 2009), http://www.icj-cij.org/docket/files/141/15638.pdf (emphasis by author).

229 DugARD, supra note 3, at 39-41 (certainly this was the case in respect of the Belgian Congo, which became independent on June 30, 1960, following a Belgian declaration to that effect of January 27, 1960). On June 14, 1960, the region of South Kasai had declared its independence, followed by the Katangan declaration of independence on July 11, 1960. CRAWFORD, supra note 7, at 57 (as far as the Congolese central government was concerned, Crawford has commented 
its claim to the territory. Not recognizing these new states on independence would have meant not recognizing any kind of sovereignty - a situation some neighbouring states may well have attempted to exploit. There was no alternative to recognizing these former colonies as states, even more so as an end to colonialism was the international community's avowed goal. The international recognition of East Timor in 2002, despite its administration still being heavily dependent on the UN, ${ }^{230}$ and therefore evidently not able to provide effective government, belongs to this category. ${ }^{231}$ The former Portuguese colony had been occupied and annexed by Indonesia in 1975. Following widespread human-rights abuses and international pressure, a referendum was held in 1999 when a large majority of the population opted for independence, which was formally achieved in 2002. Despite a lack of effective government, there was no other sovereign to turn to, once both Portugal and Indonesia had relinquished their claims. As there was no other state claiming sovereignty over these former colonies, recognising such states also corresponds to the Permanent Court of International Justice's view of territorial sovereignty:

It is impossible to read the records of the decisions in cases as to territorial sovereignty without observing that in many cases the tribunal has been satisfied with very little in the way of the actual exercise of sovereign rights, provided that the other State could not make out a superior claim. ${ }^{232}$

More recently, however, it seems that many states, often at the initiative of the United States and its European allies, are beginning to recognise entities

that "anything less like effective government it would be hard to imagine"). Nevertheless, the Democratic Republic of the Congo was swiftly recognised by many states and admitted to the United Nations.

230 See S.C. Res. 1410 (May 17, 2002) (As of 20 May 2002, a United Nations Mission of Support in East Timor (UNMISET) was established. Its duties were: “(a) To provide assistance to core administrative structures critical to the viability and political stability of East Timor; (b) To provide interim law enforcement and public security and to assist in the development of a new law enforcement agency in East Timor, the East Timor Police Service (ETPS); (c) To contribute to the maintenance of the external and internal security of East Timor.").

231 Dugard, supra note 3, at 181.

232 Legal Status of East Greenland (Den. v. Nor.), Judgment, 1933 P.C.I.J. (ser. A/B) No. 5, at 46 (Apr. 1933). 
not fulfilling the statehood criteria outside of any colonial context. ${ }^{233}$ This seems to be based on vague notions of their claim to independence being legitimate and therefore worthy of support. The widespread recognitions of Croatia, Bosnia and Herzegovina, and Kosovo, whose secessions were seen as justified in the face of Serbian aggression, seem to indicate a less stringent application of the Montevideo criteria in a non-colonial context, as these states were, and to some extent are, viable only thanks to massive international involvement in their administrations. ${ }^{234}$

Croatia declared its independence from Yugoslavia on 25 June 1991, following a referendum in May 1991, and reaffirmed this declaration on 8 October 1991. Germany recognised Croatia on 23 December 1991, on 15 January 1992 the other EC states followed suit. The USA recognised Croatia on 8 April 1992. Although disputed by some, ${ }^{235}$ there is little doubt that Croatia did not fulfil the Montevideo criteria at the time of its recognition. About one third of its territory was not under the government's control and its status as an independent state was not yet assured due to the Yugoslavian central government's military resistance. ${ }^{236}$ The Croatian war finally ended in 1995.

The situation was even clearer in the case of Bosnia and Herzegovina, which applied to the EC for recognition on 20 December 1991. ${ }^{237}$ Following a referendum held in late March 1992 (boycotted by the ethnic Serb population, around $30 \%$ of the population), Bosnia and Herzegovina, already recognised by Turkey and Bulgaria, was recognised by the EC member states on 7 April 1992, followed by the US on 8 April 1992. ${ }^{238}$ At this stage, Bosnia and Herzegovina was nowhere near meeting the state-

233 Eastwood, supra note 163, at 322, 327.

234 Referring to Bosnia and Croatia, see Koskenniemi, supra note 70, at 268; Eastwood, supra note 163 , at 327-28.

235 Weller, supra note 3, at 604.

236 Danilo Türk, Recognition of States: A Comment, 4 European Journal of International LAW 66, 69 (1993); Müllerson, supra note 71, at 130; O’Brien, supra note 12, at 186; BAER, supra note 12, at 105.

237 Türk, supra note 236, at 74.

$238 I d$. at 69. 
hood criteria. ${ }^{239}$ The government had no effective control over its territory, at times not even over the capital city, a fact acknowledged by Bosnian President Izetbegovic when - on 11 April 1992- he asked for EC, Commission on Security and Cooperation in Europe, and UN help in "prevent[ing] aggression against our peaceful country." 240

Bosnia and Herzegovina did not fulfil the criteria of statehood for many years and arguably does not until this day. In his dissenting opinion in the ICJ Genocide Convention Case, Judge Kreca pointed out that even after the 1995 Dayton Peace Accords, Bosnia's statehood remained in doubt due to massive UN involvement in its internal administrative affairs. ${ }^{241}$ As a result of those accords, the implementation of the peace settlement is still supervised by the High Representative for Bosnia and Herzegovina, who is selected by the Peace Implementation Council. ${ }^{242}$ In August 2016, more than 24 years after Bosnia and Herzegovina was recognised as an independent state, the website of the Office of the High Representative still declares: "The OHR is working towards the point where Bosnia and Herzegovina is able to take full responsibility for its own affairs." ${ }^{243}$

As mentioned earlier, recognition was viewed as justified, based on Yugoslav/Serbian aggression towards these former Yugoslav republics. Although the EC and many other states sought to refer to the secessions of Croatia and Bosnia-Herzegovina as a process of "dissolution" of the Yugoslav Republic into its constituent republics, that was evidently not the case. ${ }^{244}$ For some time afterwards Serbia and Montenegro attempted to continue the Yugoslav Republic, a move rejected by the international com-

239 Id.; O'BRIEN, supra note 12, at 186; BAER, supra note 12, at 114-15; Rich, supra note 5 , at 49 .

240 Weller, supra note 3, at 597.

241 Application of Convention on Prevention and Punishment of Crime of Genocide (Bosn. \& Herz. v. Serb. \& Montenegro), Dissenting Opinion of Judge ad hoc Kreca, 1996 I.C.J. Rep. 595, 24 (July 11).

242 Peace Implementation Council, Office of the High Representative, http:// www.ohr.int/?page_id=1220.

243 Id.; General Information, Office of the High Representative, http://www. ohr.int/?page_id=1139.

244 OTT, supra note 160, at 313-27; DUGARD, supra note 3, at 191-96; Eastwood, supra note 163 , at 300, 328; Iglar, supra note 167 , at 213-39. 
munity as it would not have suited the version of events the EC adhered to. ${ }^{245}$ Furthermore, the administrative borders of the six republics constituting the Yugoslav Federation were artificially drawn and not based on historical or ethnic realities, as evidenced by the fact that the Serb minority in Croatia wanted to remain part of Yugoslavia, as did the sizeable Serb minority in Bosnia-Herzegovina. Neither Serbs, nor Croats, together forming a majority of the population there, were initially interested in creating a new state of Bosnia-Herzegovina. Despite this, there seemed to be a vague notion among western politicians that, by prematurely recognizing Croatia and then Bosnia-Herzegovina and thus "internationalising" what had been an inner-Yugoslav conflict, the international community would be enabled to counter Serbian aggression more effectively. ${ }^{246}$ As later developments demonstrated, this approach was a colossal failure and is seen by many as actually having aggravated the conflict. ${ }^{247}$

There were similar developments as far as Kosovo is concerned. Originally, Kosovo had been an autonomous Serbian province within Yugoslavia. However, as of 1990 Serbian president Milosevic successively reduced Kosovo's status. This energized the separatist movement, which was aiming for Kosovo's independence. Following the 1995 Dayton Accords, tensions increased and both sides resorted to military force. Many Kosovars were displaced by Serbian attacks, which led NATO to intervene in 1999 by bombing Yugoslavia. On 10 June 1999, the UN Security Council passed resolution 1244 that, while affirming Yugoslavia's sovereignty, established UNMMIK - the UN administration for Kosovo - and authorized KFOR, a NATO-led peacekeeping force. Following years of peace negotiations and international supervision of its administration, Kosovo declared its independence on 17 February 2008. Kosovo was rapidly recognised by, among others, Germany, the UK, the US, and France. This despite the fact that Kosovo's government was not in effective control of its territory, but rather heavily dependent on international organizations. ${ }^{248}$ UNMIK's

245 Eastwood, supra note 163, at 328.

246 Müllerson, supra note 71, at 130; Dugard, supra note 3, at 56.

247 Hannum, supra note 3, at 62; Müllerson, supra note 71, at 131-32; O'BrIEN, supra note 12, at 186.

248 Wilde, supra note 226, at 19; DUgARD, supra note 3, at 207-09; Oeter, supra note 138 , at 66-67. 
mission meanwhile was described as follows: "The Security Council, in its Resolution 1244 (1999), has vested in the interim civil administration authority over the territory and people of Kosovo. All legislative and executive powers, including the administration of the judiciary, will, therefore, be vested in UNMIK." 249

The International Civilian Office, which continued until September 2012, could veto legislative and executive actions undertaken by the Kosovo administration. The European Union Rule of Law Mission in Kosovo (EULEX) was formed, with powers of arrest and prosecution. EULEX's mission has been extended until 14 June 2018 and includes the right to assign criminal law cases to EULEX prosecutors and to a panel with a majority of EULEX judges in "extraordinary cases". ${ }^{250}$ Against this backdrop, there must be doubts as to whether Kosovo even now, more than eight years after its widespread recognition as a new state, fulfils the statehood criteria. ${ }^{251}$ Certainly, at the time of their recognitions, same states acknowledged that much. In a press release, confirming its recognition of Kosovo, Sweden made the following statement: "A difficult and demanding process is now being started to build a Kosovan state that meets international requirements." 252

Nevertheless, major western powers rapidly recognised the putative new state, although that certainly went against the EC's original position on the inner-Yugoslav conflicts, which had declared the internal administrative borders of the Yugoslav republics sacrosanct. Kosovo undoubtedly was a part of the Serb Republic. Furthermore, the fiction of the dissolution of Yugoslavia into its constituent republics no longer could be sustained, as Kosovo was clearly seceding from the Republic of Serbia. Despite many years having passed since Serbian troops had been guilty of atrocities

249 U.N. Secretary General, Report of the Secretary General on the United Nations Interim Administration Mission in Kosovo, g 35, U.N. Doc. S/1999/779 (July 12, 1999).

250 What is EULEX?, EULEX, http://www.eulex-kosovo.eu/?page=2,16 (last updated June 21, 2016).

251 Oeter, supra note 138, at 66-68.

252 Press Release, Sweden's Ministry of Foreign Affairs, Sweden Recognises the Republic of Kosovo (Mar. 4, 2008), http://s310226652.online.de/docs/ independence/Schweden.pdf. 
against the Kosovars, ${ }^{253}$ it seems Kosovo's secession, nevertheless, was deemed justified by major powers. ${ }^{254}$ In order to avoid setting a precedent, most states, however, went out of their way to stress the sui generis situation in Kosovo. ${ }^{255}$

Many states were and are reluctant to follow the European and US lead in recognizing the territory as a new state, precisely due to doubts as to the new state's viability without international support and in order to avoid encouraging other secessionist movements. Russia, China, Spain, Greece, and India are among states that have not extended recognition. As of 8 July 2016, 109 of the 193 UN member states have, however, recognised Kosovo.

As was to be expected this attempt by mainly western states to use state recognition as a tool to achieve geopolitical goals, while nebulously indicating that this may have been down to humanitarian considerations, is being exploited by other states. ${ }^{256}$ Russia, for example, based its recog-

253 Peters, supra note 131, at 103; Oeter, supra note 138, at 64-65.

254 ICJ Self-Government of Kosovo, supra note 2; Accordance with International Law of Unilateral Declaration of Independence in Respect of Kosovo, Written Statement of Finland, 8-10 (Apr. 16, 2009), http://www.icj-cij.org/docket/files/141/15630.pdf; OTт, supra note 160, at 313-27 (explicitly arguing that these two cases prove that a right of remedial secession exists).

255 Accordance with International Law of the Unilateral Declaration of Independence in Respect of Kosovo, Written Statement of Japan (Apr. 17, 2009), http://www. icj-cij.org/docket/files/141/15658.pdf; Accordance with International Law of Unilateral Declaration of Independence in Respect of Kosovo, Written Statement of Germany, 26-27 (Apr. 15, 2009), http://www.icj-cij.org/docket/files/141/15624.pdf; Accordance with International Law of the Unilateral Declaration of Independence in Respect of Kosovo, Written Statement of Norway, gg 18, 23 (Apr. 16, 2009), http://www.icj-cij.org/docket/files/141/15650.pdf; Accordance with International Law of Unilateral Declaration of Independence in Respect of Kosovo, Written Statement of the United Kingdom, 9-15 (Apr. 17, 2009), http://www.icj-cij.org/ docket/files/141/15638.pdf; Oeter, supra note 138, at 71-72.

256 Oeter, supra note 138 , at 51, 72. 
nition of Abkhazia's and Ossetia's secession from Georgia on the Kosovo precedent. ${ }^{257}$

Although clearly not a case of secession, the case of Palestine seems to be pointing in the same direction. On November 29, 2012, the UN General Assembly (GA) decided to upgrade the State of Palestine, which had been proclaimed on November $15,1988,{ }^{258}$ from an "entity" to a "non-memberstate", 259 thereby granting it "implicit recognition as a sovereign state."260 Israel's Representative to the UN described the decision as "affixing a seal of approval onto an entity that does not meet the basic criteria of statehood." There can be little doubt that Palestine indeed does not meet the statehood criteria. Not only does its government not exercise effective control over the claimed territory, but the extent of that territory has not been agreed either. Nevertheless, 136 states have so far recognised Palestine as a state. In addition, the parliaments of the UK, France, Spain, Ireland, and Portugal have recommended that their governments also extend recognition to the State of Palestine. This success in gaining recognition is due to the fact that many states believe the Palestinians' right to self-determination should overrule the "Montevideo criteria."

It is thus possible to discern a tendency, albeit still fledgling, to weaken the Montevideo criteria of statehood even in a non-colonial context, when a secession occurs that seems justified in the eyes of the recognizing state. ${ }^{261}$ Whether this will develop into a customary international law right of remedial secession, which could then justify an exception to the prohibition on premature recognition of states, remains to be seen. Such premature recognition subsequently, of course, justifies the previously prohibited intervention in another state's affairs, as any intervention undertaken postrecognition is at the express wish of the new "state's" government. There

257 Russia Recognizes Georgia's Rebels, BBC News, Aug. 26, 2008, http://news.bbc. co.uk/2/hi/7582181.stm; Hamid \& Wouters, supra note 123, at 1; Kapustin, supra note 202, at 107; Oeter, supra note 138, at 73-74 (referring to Crimea).

258 The Declaration of Independence (Palestine 1988).

259 G.A. Res. 67/19 (Nov. 29, 2012) (passed in a 138:9:41 vote).

260 Louis Charbonneau, Palestinians Win Implicit Recognition As Sovereign State, Reuters (Nov. 29, 2012, 6:46 PM), http://www.reuters.com/article/2012/11/29/ us-palestinians-statehood-idUSBRE8AR0EG20121129.

Отт, supra note 160, at 313-27. 
are many risks inherent to this approach: of course, there will always be widely differing views as to whether the ill-defined grounds for a "remedial secession" ever existed. In its most extreme form such recognition, by internationalising a previously internal conflict, may even legitimize the use of force in collective self-defence by the recognizing state against the new "state's" parent state. ${ }^{262}$ It seems that Russia is currently following that route as far as Abkhazia, Ossetia, and the Crimean situation are concerned.

\section{CONCLUSION}

This article has set out the current customary international law on state recognition. It has been argued that clear rules have been established during the last century. As extending recognition remains at the discretion of the individual state, there is bound to be some variance in the application of these rules. This can be due to a genuine disagreement in evaluating the facts on the ground, but is probably more often the result of contradictory geopolitical goals.

Against the general backdrop of the increasing importance of humanitarian considerations in international law, as evidenced by the contested concepts of humanitarian intervention and the Responsibility to Protect, there may, however, now be a tendency to instrumentalize state recognition to further such goals.

While customary international law does not regulate the lawfulness of secessions and the recognition of a new state is simply dependent on the secession's success, it seems there may be some states willing to accept the concept of a right of remedial secession when a state's government suppresses a minority. This seems to be accompanied by a weakening of the Montevideo criteria when deciding on whether to recognise the new state resulting from such a secession, possibly justifying premature recognition.

This is still very early days, as most states have not yet expressed corresponding legal views, and state practice is still isolated and inconsistent. Such a development, however, would pose serious risks. By creating ever more loopholes in international law, whether justified on humanitarian

262 See id. at 243 (India employed this strategy by recognizing Bangladesh in early December 1971, long before Bangladesh had truly become a state, in order to justify its military intervention there). 
grounds or not, international law itself is undermined. Ill-defined criteria applied subjectively also endanger world stability: by internationalising internal conflicts -supposedly on humanitarian grounds- relatively minor conflicts can easily escalate. International law, meanwhile, is increasingly exposed to accusations of double standards: recognizing Kosovo or Bosnia and Herzegovina is justified, recognising Abkhazia or Ossetia is not - and vice versa. The last few decades have surely provided enough examples of foreign interventions, based on the claim of "new" or "emerging" norms of international law, that failed and seriously undermined international law. The law on state recognition should be preserved and not become another tool of intervention.

Far from "new thinking in the field of international law"263 as Tomuschat claims, states' evolving approach to state recognition is reminiscent of the very traditional approach to state recognition, based on the inequality of states: an exclusive group of states decides who should become a new member of the international community. It would be preferable if states avoided turning back the clock to the $19^{\text {th }}$ century when state recognition was no more than a reflection of the relative power of states.

263 Supra note 224 , at 43. 